\title{
SOVEREIGNTY OF ABORIGINAL PEOPLES
}

\author{
Julie Cassidy*
}

\begin{abstract}
It is for the people to determine the destiny of the territory and not the territory the destiny of the people. ${ }^{1}$
\end{abstract}

\section{INTRODUCTION}

The relevance of establishing Aboriginal sovereignty is not confined to the practical exercise of sovereign powers within a given jurisdiction. It is also relevant to the judicial enforcement of rights. If, as suggested by traditional theory, international law only pertains to the actions of sovereign ${ }^{2}$

* LL.B. (Hons), University of Adelaide, Ph.D., Bond University, Barrister and Solicitor, Associate Professor, School of Law Deakin University, Geelong, Australia.

1. Western Sahara, 1975 I.C.J. 12, 122 (Oct. 16) (separate opinion of Judge Dillard).

2. Sovereignty has been defined as "the basic international legal status of a State that is not subject, within its territorial jurisdiction, to the governmental, executive, legislative or judicial jurisdiction of a foreign State or to foreign law other than public international law." 10 ENCYCLOPEDIA OF PUBLIC INTERNATIONAL LAW 408 (1987). While often used interchangeably with the notion of self-government, sovereignty is technically different. While self-determination may give indigenous peoples many of the powers akin to sovereignty, it does not necessarily ensure access to particular rights, such as independence. See U.N. CHARTER art. 1, I 2; International Covenant on Civil and Political Rights, Sept. 8, 1992, art. 1, 999 U.N.T.S. 171, 6 I.L.M. 368 (1967); International Covenant on Economic, Social and Cultural Rights, G.A. Res. 2200, U.N. GAOR, 21 st Sess., Supp. No. 16, art. 1, U.N. Doc. A/6316 (1967); Declaration on the Granting of Independence to Colonial Countries and Peoples, G.A. Res. 1514, U.N. GAOR, 15th Sess., Supp. No. 16, at 66, U.N. Doc. A/4684 (1960); Discrimination Against Indiginous Peoples: First Revised Text of the Draft Universal Declaration on the Rights of Indigenous Peoples, U.N. Doc. E/CN.4/Sub.2/1989/33 (1989). Cf. G. Nettheim, Sovereignty and Aboriginal Peoples, 53 ABORIGINAL L. BULL. 4, 6 (1991) (noting that self-determination "is a process" which allows peoples to make a choice between a vast variety of relationships with the "occupying" state ranging from total integration to full independence). See also Gudmundur Alfredsson, The Right to Self-Determination and Its Many Manifestations, in THE Rights of INDIGENous PEOPLES IN INTERNATIONAL LAW: SELECTED ESSAYS ON SELF-DETERMination 53 (R. Thompson ed., 1987); Ian Brownlie, The Rights of Peoples in Modern International Law, in THE RIGHTS OF PEOPLES 5-6 (J. Crawford ed., 1988); Lea Brilmayer, Secession and Self-Determination: A Territorial Interpretation, 16 YALE J. INT'L L. 177, 201-02 (1991); John H. Clinebell \& Jim Thomson, Sovereignty and Self-Determination: The Rights of Native Americans Under International Law, 27 BUFF. L. REV. 669 (1978); L. Kelly, Reconciliation and the Implications for a Sovereign Aboriginal Nation, 61 ABORIGINAL L. BULl. 10, 11 (1993). See generally Russell Barsh, Indigenous Peoples and the Right to Self-Determination in International Law, in INTERNATIONAL LAW AND ABoriginal HuMAN Rights (Barbara Hocking ed., 1988); Elizabeth A. Pearce, SelfDetermination for Native Americans: Land Rights and the Utility of Domestic and International Law, 22 COLUM. HuM. RTS. L. REV. 361 (1991). 
states $^{3}$ and, perhaps as a corollary, only sovereign states are capable of enforcing international law, ${ }^{4}$ establishing Aboriginal sovereignty will be a necessary prerequisite to enforcing international legal rights. According to the traditional view, international responsibility is owed to the state of which the individual is a national, not the individual itself. ${ }^{5}$ As it is the state's right, and not the individual's, which has been infringed by a breach of international law, only the state may enforce that right in the international courts. The theorists supporting this proposition reason that the individual is only an "object," not a "subject," of international law. ${ }^{6}$ As a corollary, according to the traditional theory, individuals have no international rights and lack the necessary procedural capacity to enforce rights in an international court of justice. Some jurists advocating the traditional view submit that because of the lack of procedural capacity, ${ }^{7}$ individuals and substate collectives cannot be the direct beneficiaries of international rights. ${ }^{8}$

As a consequence of these traditional restrictions, individuals and minority groups typically must rely on either the United Nations or their "occupying" state to support and enforce any claims made in an international forum for breaches of international law. Unless such groups can establish

3. Traditionally, municipal law is said to deal with the actions of individuals and the domestic activities of sovereign states and international law with the international actions of sovereign states. See H. LaUTERPACHT, RÈGles GÉNÉRALES DU DROIT DE LA PAIX 129 (1938). See also 2 L. OPPENHEIM, INTERNATIONAL LAW 344 (1st ed. 1905), the chief exponent of the traditional theory who asserts that an "individual human being . . . is never directly a subject of International Law . . . . But what is the real position of individuals in International Law, if they are not subjects thereof? The answer can only be that they are objects of the Law of Nations." It is submitted, however, that this view is slowly being discarded as state practice increasingly recognizes that individuals and groups of individuals may be the direct beneficiaries of international rights, enforceable by either the individual or other states. See also Philip C. Jessup, Subjects of a Modern Law of Nations, 45 MICH. L. REV. 383, 403 (1947). A detailed discussion of the arguments for extending international law to individuals cannot be considered within the scope of this article. See Julie Cassidy, Customary International Law's Protection of Aboriginal Title in Post-Colonial Nations, ch. 20 (1993) (unpublished Ph.D. dissertation, Bond University, Queensland, Australia) (on file with author).

4. The traditional view is reflected in the STATUTE OF THE INTERNATIONAL COURT OF JUSTICE art. 34, 11 (Oct. 24, 1945), which provides "[o]nly States may be parties in cases before the Court."

5. Except in rare cases where, for example, a treaty can be construed as giving rights directly to individuals, or in cases of humanitarian intervention, other states have no interest in the breach and consequently cannot enforce these rights on behalf of aggrieved individuals or sub-state collectives. See Advisory Opinion No. 15, Jurisdiction of the Courts of Danzig (Pecuniary Claims of Danzig Railway Officials Transferred to the Polish Service), P.C.I.J. (ser. B) No. 15, at 17-21 [hereinafter Danzig]; 2 Hugo Grotius, DE JURE BELLI AC PACIS LiBRI TRES, chs. 8 \& 25 (Francis Kelsey trans., Carnegie ed. 1925) (1646).

6. See generally OPPENHEIM, supra note 3.

7. See STATUTE OF THE INTERNATIONAL COURT OF JUSTICE art. 34 , $\$$ 1-3 (Oct. 24, 1945).

8. See generally HaNS Kelsen, PRINCIPLes of InTERNATIONAL LAW (Robert W. Tucker ed., 2 d ed. 1966). 
that they have retained their sovereign rights and can be recognized as a state, ${ }^{9}$ they have no standing in, for example, the International Court of Justice, ${ }^{10}$ and must turn to municipal courts" for relief.

The latter avenue of relief is not without risks. Unless the subject of international law is a nonderogable rule of $j u s$ cogens, ${ }^{12}$ judicial practice ${ }^{13}$

9. Even if Aboriginal sovereignty is accepted in accordance with the analysis of international law contained in this article, the requirement of state recognition may nevertheless pose a considerable hurdle to the exercise of those sovereign rights. In a similar context, Bryant notes, "political recognition will no doubt turn on whether the State, exercising sovereignty over a particular indigenous group, first recognizes their selfdetermination status." Michael J. Bryant, Aboriginal Self-Determination: The Status of Canadian Aboriginal Peoples at International Law, 56 SASK. L. REV. 267, 269 (1992). Cf. S.A. Williams, International Legal Effects of Secession by Quebec, in YORK UNIVERSITY CENTRE For PUBLIC LAW AND PUBLIC POLICY, FINAL REPORT OF THE YORK UNIVERSITY CONSTITUTIONAL REFORM PROJECT, STUDY No. 8, at 11-12 (1992). See also the comments of Frank Brennan, Mabo and Its Implications for Aborigines and Torres Strait Islanders, in MABO: A Judiclal Revolution 24, 26-27 (M. A. Stephenson \& Suri Ratnapala eds., 1993). Given the current climate in countries such as Canada and Australia, it is unlikely that claims of Aboriginal sovereignty would be supported by the "occupying" state. This is particularly so where the claims to sovereignty are in a form that threatens the "occupying" state's territorial integrity. In this regard Bryant notes that, as a matter of political reality, as opposed to legal theory, an "occupying" "State's territorial integrity will almost always trump the wishes of a minority of citizens." Bryant, supra, at 268. See generally Kelly, supra note 2 (discussing the alternative ways that sovereignty may be exercised or accommodated).

10. See StatuTe of THE InTERnational Court of Justice art. 34, 11 (Oct. 24, 1945).

11. Note, traditionally, under the dualist view, municipal and international law are said to operate in two distinct spheres; the former dealing with the actions of individuals and the domestic activities of sovereign states and the latter with the international actions of these sovereign states. See 1 DiONISIO ANZILOTTI, CORSO DI DiRITTO INTERNAZIONALE 43 (3d ed. 1928). See also generally HEINRICH TRIEPEL, VÖLKERRECHT UND LANDESRECHT (1899). Under the alternative monist view, however, these bodies of law are not seen as being discrete. See KELSEN, supra note 8, at 553-88. See generally WILlIAM BLACKSTONE, COMMENTARIES ON THE LAWS OF ENGLAND, ch. 5 (8th ed. 1778); 1 OPPENHEIM, supra note 3, ch. 4; J.G. STARKE, AN INTRODUCTION TO INTERNATIONAL LAW (7th ed. 1972); supra discussion note 3 . For a discussion of how customary international law flows into domestic legal forums and may be enforced by individuals in municipal courts, see Lord Atkin's comments in Chung Chi Cheung v. The King [1939] App. Cas. 160, 167-68 (P.C. 1938) (appeal taken from H.K.). A detailed discussion of the arguments for applying international law in the municipal courts cannot be considered within the scope of this article. See generally Cassidy, supra note 3 , ch. 21 . As to the validity of the monist view, see generally Filartiga v. Pena-Irala, 630 F.2d 876 (2d Cir. 1980).

12. These are nonderogable norms reflecting principles crucial to maintaining the international legal order. See Antonio Cassese, The Self-Determination of Peoples, in THE InTERnAtional BILl of Rights: The Covenant on Civil and Political Rights 92, 111 (Louis Henkin ed., 1981). They cannot be derogated from by treaty, protest, or acquiescence. Any agreements or actions contrary to such a law are absolutely void. See id. Not even prescription can purge a breach of a rule of jus cogens. These laws can only be replaced or modified by a subsequent norm of the same peremptory character, a subsequent norm of jus cogens. A detailed discussion of jus cogens cannot be considered within the scope of this article. For a discussion of jus cogens, see Christopher P. Cline, Pursuing Native American 
suggests that inconsistent domestic law can prevail over international law in the municipal arena. ${ }^{14}$ If a legislature's intent to legislate inconsistently with international law $^{15}$ is evident from the face of municipal legislation, municipal courts are bound to give effect to that legislation. ${ }^{16}$ As Lord Porter noted in Theophile v. Solicitor-General:

[There is a presumption] that Parliament does not assert or assume jurisdiction which goes beyond the limits established by the common consent of nations. On the principles already stated, however, this presumption must give way before an intention clearly expressed. ... . Statutes are to be interpreted, provided that their language admits, so as not to be inconsistent with the comity of nations. [However, if the] statutory enactments are clearly inconsistent with international law, they must be so construed, whatever the effect . . . within the jurisdiction may be. ${ }^{17}$

A violating state could, therefore, prevent Aboriginal claimants from enforcing international rights in its municipal courts with relative ease by

Rights in International Law Venues: A Jus Cogens Strategy after Lyng v. Northwest Indian Cemetery Protective Association, 42 HASTINGS L.J. 591, 619-24 (1991). For the author's discussion of this matter, see Cassidy, supra note 3, ch. 26.

13. In contrast to judicial practice, academics give primacy to international law. See generally HERSCH LAUTERPACHT, INTERNATIONAL LAW AND HUMAN RIGHTS (1973); Cassidy, supra note 3 , ch. 21.

14. According to this view, international law prevails, but only "so far as it is not inconsistent with rules enacted by statutes or finally declared by their tribunals." Chung Chi Cheung [1939] App. Cas. at 167-68.

15. There is a strong presumption against such inconsistency. Domestic legislation is to be construed to avoid conflict with international norms. As the Court declared in Murray v. The Schooner Charming Betsy, "an act of Congress ought never to be construed to violate the law of nations if any other possible construction remains." 6 U.S. (2 Cranch) 64, 118 (1804). "In cases admitting of doubt, the presumption would be that Parliament intended to legislate without violating any rule of international law ..." The Annapolis [1861] 1 Lush. 295, 306 (Can.). See, e.g., McCulloch v. Sociedad Nacional, 372 U.S. 10, 21 (1963); The Antelope, 23 U.S. (10 Wheat.) 66, 116-18 (1825); Peters v. McKay, 238 P.2d 225, 231 (Or. 1951), reh'g denied, 246 P.2d 535 (Or. 1952); The Queen v. Foster (1959) 104 C.L.R. 256, 307 (Austl.); Polites v. Commonwealth (1945) 70 C.L.R. 60, 68-81 (Austl.); In re Noble \& Wolf [1948] 4 D.L.R. 123, 139 (Can.); In re Arrow River \& Tributaries Slide \& Boom Co. [1932] 2 D.L.R. 250, 259-61 (Can.); Theophile v. Solicitor-General [1950] App. Cas. 186, 195-96 (1949) (appeal taken from Eng.); Croft v. Dunphy [1933] App. Cas. 156, 162-63 (P.C. 1932) (appeal taken from Can.); In re Republic of Bolivia Exploration Syndicate Ltd., $1 \mathrm{Ch}$. 139 (1914) (Eng.); The Queen v. Keyn, 2 Ex. D. 63, 85 (1876) (Eng.). Cf. The Queen v. Carr, 10 Q.B.D. 76 (1882).

16. See, e.g., Foster, 104 C.L.R. at 307; Theophile, [1950] App. Cas. at 195-96; Keyn, 2 Ex. D. at 85.

17. Theophile, [1950] App. Cas. at 195-96 (quoting 31 HALSBURY's LAws OF ENGLAND 508-09 (2d ed. 1938)). See, e.g., Foster, 104 C.L.R. at 307; Keyn, 2 Ex. D. at 85. 
enacting inconsistent domestic legislation. ${ }^{18}$ Consequently, the existence of Aboriginal sovereignty is important not only to the enjoyment of sovereign rights, but to the enforcement of any rights founded in international law. ${ }^{19}$

The sovereignty of indigenous populations has long been a matter of great dispute and continues to be one of the most burning issues in domestic and international law today. ${ }^{20}$ Contrary to popular belief, international law, both in the past and today, is not entirely eurocentric and "amoral," ${ }^{21}$ and historically many international jurists have been sympathetic to protecting Aboriginal sovereignty and territorial rights. ${ }^{22}$ To this end, state practice reveals a consistent recognition of the legal incidents stemming from Aboriginal occupation of land ${ }^{23}$ International law generally acknowledged the sovereignty of these peoples and saw indigenous possession as preventing land from being classified as terra nullius, or open to acquisition by mere occupation. ${ }^{24}$

The international law doctrine of reversion also provides for the continuance and ultimate resurrection of these sovereign rights after purported acquisitions by European imperial forces. Under this doctrine, despite the pretense of effective occupation, the sovereign rights of Aboriginal people lie dormant awaiting reversion. It is this sovereignty ${ }^{25}$ that

18. A state which so acts breaches international law and may as a consequence be subject to international sanction. See Advisory Opinion No.10, Exchange of Greek and Turkish Populations, 1925 P.C.I.J. (ser. B) No. 10, at 20.

19. For example, the author has suggested that customary international law recognizes and protects Aboriginal title. See generally Cassidy, supra note 3.

20. For an example of such a dispute, see the controversy that stemmed from the decision in Alaska v. Native Village of Venetie Tribal Gov't, 101 F.3d 1286 (9th Cir. 1996) (upholding the Venetie's sovereign rights), rev'd, 118 S. Ct. 948 (1998).

21. See, e.g., James Crawford, THE CREATION OF STATES IN INTERNATIONAL LAW 173 (1979).

22. Perhaps the most famous being Francisco de Vitoria, De Indis et de Ivre Belli Relectiones [Reflections on the Indians and on the Law of War], in CLASSICS OF INTERNATIONAL LAW (James Scott ed., 1917) (1557). See also Rachel San Kronowitz et al., Toward Consent and Cooperation: Reconsidering the Political Status of Indian Nations, 22 HARV. C.R-C.L. L. REv. 507 (1987); G. Marks, Indigenous Peoples in International Law: The Significance of Francisco de Vitoria and Bartoleme de las Casas (1990) (unpublished thesis, Faculty of Law, Australian National University) (on file with author).

23. See Cassidy, supra note 3.

24. Under modern international law it is unlawful to purport to acquire sovereign and territorial rights through conquest or settlement of occupied lands. See, e.g., U.N. CHARTER art. 2, I9 1-4; Western Sahara, 1975 I.C.J. 12, 123 (Oct. 16) (separate opinion of Judge Dillard); Legal Consequences for States of the Continued Presence of South Africa in Namibia (South West Africa) Notwithstanding Security Council Resolution 276 (1970), 1971 I.C.J. 16, 91 (June 21) (separate opinion of Vice-President Ammoun) [hereinafter Namibia].

25. Some authors have suggested natural law as an alternative source of sovereign rights. See Brian Slattery, Aboriginal Sovereignty and Imperial Claims, 29 OsGOODE HALL L.J. 681, 696-703 (1991). 
the Aboriginal peoples call to be recognized today. ${ }^{26}$

This article considers international law's recognition of Aboriginal sovereignty. ${ }^{27}$ The status of Aboriginal peoples in international law involves many difficult questions relating to the acquisition of territory and the recognition of Aboriginal sovereignty. In Part II, a number of doctrines ${ }^{28}$ often put forward as barriers to claiming Aboriginal sovereignty are considered and it is submitted that these doctrines do not preclude claims from being successfully made. Part III examines issues that more closely pertain to international law's recognition of Aboriginal sovereignty. This includes a discussion of international law's recognition of Aboriginal occupation and sovereignty. Part IV concludes with a discussion on the

26. For example, the Chairman of the Northern Land Council, Mr. Galarrwuy Yunupingu declared in 1987: "Aboriginal People are the indigenous sovereign owners of Australia and adjacent islands since before 1770 and as such have rights and treaty rights. Their Sovereignty has never been ceded . . . . B. Weatherall, Foundation of Aboriginals and Islander Research Action, WKND. AUSTL., June 30-July 1, 1990, at 21. See generally STANDING COMMITTEE ON CONSTITUTIONAL AND LEGAL AFFAIRS (AUSTL.), TWO HUNDRED YEARS LATER, 12.6 (1983) [hereinafter Standing COMMITTEE]. The Standing Committee stated:

We have never conceded defeat and will continue to resist this on-going attempt to subjugate us. . . . The Aboriginal people have never surrendered to the European invasion and assert that sovereignty over all Australia lies with them. ... [W] demand that the colonial settlers who have seized the land recognize this sovereignty and on that basis negotiate their right to be there.

Id. That the Aboriginal peoples of Australia have "neither ceded their lands to the Crown nor suffered them to be taken as the spoils of conquest" was recognized by the High Court of Australia. Mabo v. Queensland (1992) 175 A.L.R. 1, 29 (Austl.). In July 1990, members of the Australian Aboriginal Community established an Aboriginal Provisional Government representing the Aboriginal peoples claims to sovereign rights. It was established in response to the need for "a new national structure which, by its very name will tell the world we are a sovereign people, fighting for our sovereign rights." Weatherall, supra. See generally Kelly, supra note 2; N. Pearson, Reconciliation to Be or Not to Be, 61 ABORIGINAL L. BuLL. 14 (1993). With respect to Canadian Aboriginal peoples,. see Speaking Notes for National Chief, Ovide Mecredi, in CONSTITUENT ASSEMBLy ON THE RENEWAL OF CANADA, IDENTITY, RIGHTS AND VALUES: SPEECH BEFORE THE ASSEMBLY OF FIRST NATIONS (1992) (calling for the recognition of their "collective rights" and respect for their "cultures, languages, governments and spirituality"). See also MiCHAEL ASCH, HOME AND NATIVE LAND: ABORIGINAL RIGHTS AND THE CANADIAN CONSTITUTION 29 (1984); Michael Asch, Aboriginal Self-Government and the Construction of Canadian Constitutional Identity, 30 ALTA. L. REV. 465,491 (1992).

27. The following discussion will concentrate on Aboriginal sovereignty, rather than the right to self-determination. Some of the discussion will nevertheless advert to the latter doctrine. See supra text accompanying note 2 for a brief discussion of the meaning of sovereignty.

28. Other doctrines asserted as preventing claims of Aboriginal sovereign rights have also been introduced previously in this article. In particular, see supra notes 3-11 and accompanying text for a discussion of the applicability of international law to individuals and sub-state collectives. See supra notes 11-19 and accompanying text for a discussion of the enforceability of international law in municipal courts. 
ability of Aboriginal communities to reclaim their sovereignty today.

\section{DOCTRINES LIMITING ClAIMS OF SOVEREIGNTY}

\section{A. Intertemporal Rule}

A necessary preliminary to discussing international law's recognition of Aboriginal sovereignty is an appreciation of its practical relevance today. An academic discussion of the works of legal jurists is of little value if other international law doctrines prevent Aboriginal sovereignty from being invoked. At times, the intertemporal rule ${ }^{29}$ has been mistakenly interpreted as requiring the validity of sovereign rights to be determined in light of the law prevailing at the time of the original acquisition of land, ${ }^{30}$ rather than the critical point $^{31}$ of any later dispute. This erroneous application of the rule has allowed "occupying" governments to attempt to validate their occupation on mistaken ${ }^{32}$ assertions that international law, at the time of their initial settlement or conquest of Aboriginal lands, validated the acquisition of sovereign and territorial rights.

It is submitted below that, as of the date of the purported acquisition of sovereign and territorial rights over countries such as Australia, Canada, and the United States of America, international law recognized Aboriginal occupation and sovereignty in a manner that would negate the legitimacy of claims of sovereign title based on, for example, the settlement of these lands. If, however, this interpretation of international law is erroneous, it is contended that the legitimacy of these governments' sovereignty can nevertheless be questioned pursuant to the intertemporal rule.

For some reason, "occupying" governments have failed to recognize that under this rule international law at the time of the purported annexation does not provide the only source of legal authority for determining the existence of Aboriginal sovereign rights and, thus, the validity of any purported acquisition. ${ }^{33}$ Most importantly, the intertemporal rule requires rights which are perpetually exercised to continue to conform with

29. A comprehensive discussion of this notion is beyond the scope of this article. For a more complete discussion, see Cassidy, supra note 3 , ch. 25.

30. See, e.g., STANDING COMMITTEE, supra note 26, $\{3.36$; Coe v. Commonwealth (1979) 53 A.L.J.R. 403 (Austl.); Milirrpum v. Nabalco Party Ltd. (1971) 17 F.L.R. 141 (Austl.); Cooper v. Stuart [1889] 14 App. Cas. 286 (P.C. 1889) (appeal taken from N.S.W.).

31. See Minquiers and Ecrehos (Fr. v. U.K.), 1953 I.C.J. 47, 59 (Nov. 17).

32. It is submitted below that international law at the time of the purported acquisitions recognized Aboriginal sovereignty and thus would not support claims of a valid acquisition of sovereignty.

33. It could be suggested that it is an engineered falsehood designed to discourage claims for Aboriginal sovereignty. See also Coe, 53 A.L.J.R. at 429 (setting forth Justice Murphy's suggestion that statements supporting the "settlement" of Australia were "made in ignorance or as a convenient falsehood to justify the taking of aborigines' land"). 
international law as it develops. The validity of these rights must be considered in light of international law as it stands at the "critical date" of the dispute. ${ }^{34}$ Thus, as Arbitrator Huber noted in Island of Palmas, through the intertemporal rule, international legal developments can retrospectively invalidate or detract from sovereign rights, even though these rights may have been legitimately obtained according to international law at the time of the original annexation. ${ }^{35}$

Accordingly, as sovereign and territorial rights must be continually asserted, their legitimacy must be determined in accordance with international law as it develops, recognizing the demise of old principles of law and the evolution of new axioms acknowledging the rights of Aboriginal peoples. Consequently, even if state practice at the date of annexation did not recognize Aboriginal sovereignty, in the absence of protest by a state, and arguably even in such cases, ${ }^{36}$ it is international law as it stands at the critical date ${ }^{37}$ which determines the rights of the subject Aboriginal peoples. Thus, if the sovereign rights of "occupying" states were by modern standards wrongly acquired, they must not only be effectively exercised throughout the period of occupation, but also "re-acquired" in accordance with these modern international developments. This is especially so if the emerging international law recognizing Aboriginal territorial and sovereign rights is a peremptory norm of jus cogens, ${ }^{38}$ which may require the restitution of those rights purportedly acquired by the "occupying" state. ${ }^{39}$ To this end, it is important to note that under modern international law the acquisition of sovereignty in the subject countries would clearly be unlawful. Conquest is no longer a legal basis for acquiring sovereign rights, except in

34. The critical date of a dispute is the point in time at which the merits of the parties' claims are determined. At this point the situation between the parties is said to have "crystalized" and the actions of the parties after that date cannot change the legal position between the parties. See Minquiers and Ecrehos, 1953 I.C.J. at 59. For example, in Minquiers and Ecrehos, there had been prior disagreements between the parties, but these had not been linked to the question of sovereignty. See id. The relevant dispute had not, therefore, "crystalized" before the special agreement of December 29, 1950. See id. By contrast, the critical date was much earlier in the nineteenth century, when the Treaty of Paris attempted to cede the Philippines to the United States. See Arbitral Award Rendered in Conformity with the Special Agreement Concluded on January 23, 1925 Between the Unitded States of America and the Netherlands Relating to the Arbitration of Differences Respecting Sovereignty Over the Island of Palmas (or Miangas) (U.S. v. Neth.), 2 R.I.A.A. 829 (Perm. Ct. Arb. 1928), reprinted in 22 AM. J. INT'L L. 867, 872-73 (1928) [hereinafter Island of Palmas].

35. See generally Island of Palmas, 22 AM. J. INT'L L. 867 (1928).

36. If these principles are nonderogable principles of jus cogens, even protest will not undermine their effectiveness. See discussion supra note 12.

37. See discussion supra note 34.

38. These are nonderogable norms that are crucial to maintaining the international legal order. See discussion supra note 12.

39. Restitution of the purportedly acquired rights supports the reversion of sovereignty. 
the case of a just war,,$^{40}$ and sovereign rights to occupied lands may not be acquired by mere settlement. ${ }^{41}$

\section{B. Act of State}

\section{Common Law Courts}

As with the intertemporal rule, the act of state doctrine ${ }^{42}$ has been used in Australia to discourage Aboriginal claims to sovereign rights. Under this doctrine, certain executive acts are declared to be questions of law, rather than fact, which are determined by the executive and thus cannot be subsequently reviewed by the judiciary. ${ }^{43}$ Even supporters of the "Aboriginal cause," such as Frank Brennan, have asserted that a claim of Aboriginal sovereignty is "unarguable" as it "is a political claim, not a justiciable legal claim in either international or domestic courts." 44 Similarly, the High Court of Australia has held that the validity of the Australian Crown's acquisition of sovereignty is a nonjusticiable act of state. $^{45}$

40. See U.N. CHARTER art. 2, I 4; D. SANDERS, THE RE-EMERGENCE OF INDIGENOUS QUESTIONS IN INTERNATIONAL LAW 26-27 (1983).

41. See generally Western Sahara, 1975 I.C.J. 12 (Oct. 16).

42. A comprehensive discussion of the act of state doctrine and its United States equivalent cannot be undertaken here. See Cassidy, supra note 3, ch. 22 for a discussion of the act of state doctrine. It has also been suggested that an independent doctrine, known as the political question doctrine, may prevent the consideration of a dispute because of its political nature. Thus, in South Australia v. Commonwealth, Chief Justice Dixon stated that a distinction had to be drawn between, "on the one hand, the exercise of the jurisdiction reposed in the Court and, on the other hand, an extension of the Court's true function into a domain that does not belong to it, namely, the consideration of undertakings and obligations depending entirely on political sanctions." (1962) A.L.R. 547, 548 (Austl.). In that case there was no legal standard available to the Court to determine the dispute as the dispute was based on a political agreement, rather than a legal contract. See generally id. Where, however, legal standards, such as international law, exist for determining the dispute, the courts can turn to these tenets to decide the case; they do not have to make a political judgment. See Cassidy, supra note $3, \mathrm{ch} .22$. It will be seen that the sentiments underlying the political question doctrine are echoed in the United States act of state doctrine.

43. See generally Secretary of State v. Kamachee Boye Sahaba, 15 Eng. Rep. 9 (P.C. 1859) (appeal taken from Madras). Cf. S.A. DE SMITH, Constitutional AND ADMINISTRATIVE LAW 135 (2d ed. 1973).

44. See Brennan, supra note 9, at 26. See also Frank Brennan, The Year of Living Harmoniously, AUSTL., Apr. 1, 1992, at 5.

45. See, e.g., Wik Peoples v. Queensland (1996) 141 A.L.R. 129, 250 (Austl.); Mabo v. Queensland (1992) 175 C.L.R. 1, 32-33, 78-79, 95, 138 (Austl.); Coe v. Commonwealth (1979) 53 A.L.J.R. 403, 408, 410-11 (Austl.); New South Wales v. Commonwealth (1975) 135 C.L.R. 337, 338 (Austl.). Thus, in Coe, Justice Gibbs held that the classification of the Australian continent was so "fundamental to our legal system" that a claim of Aboriginal sovereignty was not fit for consideration. Coe, 53 A.L.J.R. at 408 . He declared "the question is not how the manner in which Australia became a British possession might appropriately be described," but how the Crown decided to classify the colony. Id. Justice 
Thus, it is necessary to consider whether the common law act of state doctrine and its United States equivalent prevents Aboriginal claimants from asserting their sovereign rights in a judicial forum. Before the municipal application of these doctrines is considered, it is important to note that contrary to Brennan's suggestion, the act of state doctrine does not bar a matter being litigated in an international forum. Western Sahara ${ }^{46}$ indicates that questions pertaining to sovereign and territorial rights ${ }^{47}$ will be considered by the International Court of Justice. ${ }^{48}$ Moreover, despite the

Jacobs also asserted:

the statement of claim . . . apparently intended to dispute the validity of the British Crown's and now the Commonwealth of Australia's claim to sovereignty over the continent of Australia. . . . These are not matters of municipal law but the law of nations and are not cognizable in a Court exercising jurisdiction under that sovereignty which is sought to be challenged.

Id. at 411. In Mabo, Justice Brennan declared that the annexation of the Murray Islands was a prerogative act "the validity of which is not justiciable in the municipal courts." Mabo, 175 C.L.R. at 32. Similarly, Justice Dawson asserted that the annexation "was an act of state by which the Crown in right of the Colony of Queensland exerted sovereignty over the islands. ... [T] here can be no doubt that it was, and remains, legally effective." Id. at 138 (footnote omitted). For similar conclusions, see the comments in Wik Peoples, 141 A.L.R. at 289-90. In Wik Peoples, Justice Kirby stated that the subject dispute was "not . . . a matter for legal but only for political redress." Id. at 290 (footnote omitted). See also Milirrpum where Justice Blackburn held that the classification of the annexation of the Australian continent was a matter of law, not fact, and was not open to judicial review. Milirrpum v. Nabalco Party Ltd. (1971) 17 F.L.R. 141, 243 (Austl.).

46. 1975 I.C.J. 12 (Oct. 16). The question in this case was whether the Western Sahara was terra nullius at the time of colonization. See id. at 14. The lawfulness of Spain's acquisition of sovereignty over the subject territory was not considered. See id. at 123 (separate opinion of Judge Dillard). Cf. Rosalie Balkin, International Law and Sovereign Rights of Indigenous Peoples, in INTERNATIONAL LAW AND ABORIGINAL HuMAN RIGHTS 19, 33 (Barbara Hocking ed., 1988).

47. These concepts include the reversion of sovereignty. See infra Part IV for a discussion of the reversion of sovereignty.

48. Problems pertaining to standing would, however, have to be overcome. As noted earlier, only "States may be parties in cases before the Court." STATUTE OF THE INTERNATIONAL COURT OF JUSTICE art. 34, I 1 (Oct. 24, 1945). Thus, to bring a claim in this court an Aboriginal claimant would have to establish statehood. To some degree this gives rise to what may be colloquially called a "chicken or egg" problem. While the claimant is seeking to have the existence of Aboriginal sovereignty determined by the court, to have standing the claimant needs to establish Aboriginal sovereignty. One way of avoiding this circularity is to have the International Court of Justice, at the request of the General Assembly or the Security Council of the United Nations, give an advisory opinion on the matter. See U.N. CHARTER art. 96, I 1. See also U.N. CHARTER art. 65 (allowing the Economic and Social Council to furnish information to the Security Council and requiring the Economic and Social Council to assist the Security Council upon the Security Council's request). While such an opinion would not be legally binding on the "occupying" state, it would provide strong political impetus for the recognition of Aboriginal sovereignty. Note, the factual nature of such a consideration would not prevent the International Court of Justice determining the matter as long as the dispute involved mixed questions of law and fact. See Western Sahara, 1975 I.C.J. 12, 19 (Oct. 16). See generally Namibia, 1971 I.C.J. 16 (June 21). 
possible ramifications in the domestic arena, ${ }^{49}$ such a determination would be effective in the municipal legal system to the extent that international law becomes operative in that forum.

Even in the domestic context, the act of state doctrine has its limits and may not always be used by a government to prevent a judicial consideration of a particular matter. First, not all government acts are acts of state. ${ }^{50}$ At common law, the term "act of state" connotes a variety of acts carried out in pursuance of the royal prerogative. However, not all prerogative acts are acts of state. ${ }^{51}$ Only those acts which are "part of or necessarily incidental to a high-level policy decision (and possibly other acts expressly ratified by the Crown) will be treated as acts of state." ${ }^{52}$ While the annexation of a country falls within this category of executive acts, ${ }^{53}$ it has been suggested that the act of state doctrine does not prevent an examination of the state of the relevant law at the time of the purported annexation. Thus, in Coe $v$. Commonwealth, while Justice Jacobs, along with the other members of the High Court of Australia, held that the validity of the actual acquisition of Australia was not justiciable, he asserted that its quality in point of common law theory was open to consideration. ${ }^{54}$ What the law declares on a matter is not an act of state. Thus, a court could make a finding upon, for example,

49. However, "[n]othing contained in the present Charter shall authorize the United Nations to intervene in matters which are essentially within the domestic jurisdiction of any state." U.N. CHARTER art. 2, 17 . In practice, article 2, paragragh 7 has not prevented the United Nations from taking action with respect to breaches of human rights and the furtherance of the right to self-determination within a state's "domestic" jurisdiction. See IAN BROWNLIE, PRINCIPLES OF PUBLIC INTERNATIONAL LAW 294 (3d ed. 1979).

50. There is no concise definition of act of state. See DE SMITH, supra note 43, at 135. For example, the Court of Appeals, Civil Division was unable to reach a majority view as to the definition of act of state in Nissan v. Att'y Gen., 2 All E.R. 1238 (C.A. 1967).

51. For a discussion of the distinction drawn between prerogative powers and acts of state, see Commercial and Estates Co. of Egypt v. Board of Trade, 1 K.B. 271, 294-97 (C.A. 1925).

52. See DE SMITH, supra note 43, at 137 . In most cases these are high "exercise[s] of sovereign power." Salaman v. Secretary of State, 1 K.B. 613,639 (C.A. 1906).

53. See, e.g., Mabo v. Queensland (1992) 175 C.L.R. 1, 32-33, 78-79, 95, 138 (Austl.); In re Phillips (1987) 72 A.L.R. 508, 510-11 (Austl.); Coe v. Commonwealth (1979) 53 A.L.J.R. 403, 408, 410 (Austl.); New South Wales v. Commonwealth (1975) 135 C.L.R. 337, 338 (Austl.) (Gibbs, J., dissenting); Nissan v. Att'y Gen., 2 All. E.R. 1238, 1246 (H.L. 1967). See also supra text accompanying note 43. In New South Wales, Justice Gibbs stated that the "acquisition of territory by a sovereign state for the first time is an act of state which cannot be challenged, controlled or interfered with by the courts of that state." New South Wales, 135 C.L.R. at 338 (Gibbs, J., dissenting). Justice Gibbs repeated this view in Coe where he stated that the "annexation of the east coast of Australia by Captain Cook in 1770, and the subsequent acts by which the whole of the Australian continent became part of the dominions of the Crown, were acts of state whose validity cannot be challenged." Coe, 53 A.L.J.R. at 408.

54. Coe, 53 A.L.J.R. at 411. 
the law governing the classification of land as terra nullius ${ }^{55}$ or whether international law recognized the sovereign rights of Aboriginal peoples. This could in turn provide the impetus for the political recognition of Aboriginal sovereignty.

Second, a plea of act of state cannot be made against a subject or resident alien. ${ }^{56}$ The rationale underlying the differential application of the plea rests upon the notion that those who owe allegiance to the Crown are entitled to the protection of, or from, the Crown and are not, therefore, to be barred from making legitimate claims through the plea of act of state. ${ }^{57}$ By contrast, the plea may be made against foreigners, for they do not owe allegiance to the Crown and can look to their own government for redress.

According to the principles governing the annexation of territory, the indigenous inhabitants of lands acquired by "settlement" 58 are considered subjects of the state. ${ }^{59}$ Consequently, if the annexation of Australia," Canada, ${ }^{61}$ New Zealand, ${ }^{62}$ and the United States ${ }^{63}$ is taken to be by

55. A discussion of terra nullius is reserved for later portions of this article. See discussion supra, Part III(A).

56. See Nissan, 2 All E.R. at 1246. See generally Walker v. Baird, 1892 App. Cas. 491 (P.C. 1892) (appeal taken from Nfld.).

57. See DE SMITH, supra note 43, at 139.

58. Note that in In re Phillips, Justice Neaves held:

[t]he question whether the colony of New South Wales was acquired by settlement or by conquest would have significance in determining whether the common law was introduced into the newly acquired territory. But, in my opinion, the distinction has no significance in determining whether, in 1987, descendants of those who in 1770 or 1788 were inhabitants of what became the colony of New South Wales . . . are subject to laws enacted by the Commonwealth Parliament in exercise of the powers conferred upon it by the Constitution.

In re Phillips (1987) 72 A.L.R. 508, 512 (Austl.).

59. See The Queen v. Wedge (1976) 1 N.S.W.L.R. 58 (Austl.); The King v. Murrell, (1836) Legge 72 (Austl.), reprinted in A SELECTION OF SUPREME COURT CASES IN NEW SOUTH WALES 72, 73 (1896). See also In re Phillips, 72 A.L.R. at 511-12; Coe v. Commonwealth (1979) 53 A.L.J.R. 403, 408 (Austl.). In Coe, Justice Gibbs asserted that "[t]he Aboriginal people are subject to the laws of the Commonwealth and of the States or Territories in which they respectively reside." Id.

60. See Mabo v. Queensland (1992) 175 C.L.R. 1, 33, 180 (Austl.); Coe, 53 A.L.J.R. at 408; Milirrpum v. Nabalco Party Ltd. (1971) F.L.R. 141, 243 (Austl.); Cooper v. Stuart, 14 App. Cas. 286, 291 (P.C. 1889) (appeal taken from N.S.W.). Note in Coe, Justices Murphy and Jacobs held that it was open to an Aboriginal claimant to argue that Australia was acquired by conquest. Justice Murphy asserted that the plaintiff was "entitled to endeavour to prove ... that the lands were acquired by conquest, and to rely upon the legal consequences which follow[ed]." Coe, 53 A.L.J.R. at 412. Similarly, Justice Jacobs held that "[t]he plaintiff should be entitled to rely on the alternative arguments [to the settled classification] when it comes to be determined whether the Aboriginal inhabitants of Australia had and have any rights in land." Id. at 411. See also In re Phillips, 72 A.L.R. at 511-12.

61. See, e.g., Van der Peet v. The Queen [1996] 137 D.L.R. 4th 289, 330 (Can.); The Queen v. Sparrow [1990] 70 D.L.R. 385, 401 (Can.); Calder v. Att'y Gen. of British Columbia [1973] S.C.R. 313, 328-29, 383, 401-02 (Can.). See generally Patrick Macklem, 
settlement, as the courts have largely characterized such acquisitions, the act of state doctrine may not be utilized by the Crown to prevent Aboriginal claims.

It may be thought that Aboriginal peoples' denials of any allegiance to the Crown ${ }^{64}$ may serve to negate this principle and allow the act of state doctrine to be plead against Aboriginal claimants as if they were foreigners. ${ }^{65}$ However, if the status of a subject is automatically accorded to the Aboriginal peoples of a "settled" country as a matter of law, this status would be unaffected by claims of non-allegiance. The latter mode of reasoning is supported by the Australian judiciary's insistence that English or Australian law applies to all subjects, ${ }^{66}$ including Aboriginal occupants, ${ }^{67}$ despite claims that the courts have no jurisdiction over Aboriginal persons. ${ }^{68}$

Even if the subject countries were acquired by conquest, the act of state doctrine still could not be plead against the traditional indigenous occupants. Aliens living within Her Majesty's dominions are said to owe local allegiance

Normative Dimensions of an Aboriginal Right of Self-Government, 21 QUEEN's L.J. 173 (1995).

62. It has been suggested that the North Island of New Zealand was acquired by conquest and that the South Island was acquired by settlement. In this regard, note Lieutenant-Governor Hobson's Proclamation of May 21, 1840, declaring the South Island to have been acquired by settlement, while the North Island by cession. Fears of French occupation led the British to hurriedly declare the South Island to be taken by settlement and to set up around the country "dummy" signs of occupation.

63. See Johnson v. M'Intosh, 21 U.S. (8 Wheat.) 543 (1823).

64. In Murrell, defense counsel Stephens questioned the court's jurisdiction over Aboriginal offenders in cases of offenses inter se. See The King v. Murrell, (1836) Legge 72 (Austl.). Utilizing Rousseau's social contract theory, Counsel Stephen's argued that as the defendants had not consented to the Crown's sovereignty, they were not amenable to the Crown's law. See id. As the Crown had failed to protect Aboriginal persons and property, consent could not be implied and, consequently, there was no legitimate basis for subjecting the defendants to the rigors of the Crown's laws. See id. Stephens also submitted that Australia was neither conquered, ceded nor settled; the Australian colonists just "moved" into Aboriginal society. See id. Consequently, the laws of England did not flow into the colony to govern the actions of all inhabitants. As the colonists moved into Aboriginal society they should be subject to Aboriginal customary law, rather than vice versa. See id. As noted above, the submission failed. For a more recent example of a refusal to accept that an Aboriginal person was not subject to the laws of Australia, see In re Phillips, 72 A.L.R. at 511-12.

65. See generally the discussion of this matter in Coe v. Commonwealth (1979) 53 A.L.J.R. 403 (Austl.).

66. See In re Phillips, 72 A.L.R. at 511-12; Wedge, (1976) 1 N.S.W.L.R. at 581; The King v. Murrell (1836) Legge 72, $72-73$ (Austl.).

67. The inclusion of Aboriginal occupants has been confirmed in multiple governors' instructions and proclamations. See, e.g., Proclamation 28 Dec. 1836, SOUTH Australian GAZETTE \& COlONIAL REgISTER, June 3, 1837. See also Governor Macquarie's Proclamation to the Aboriginals, 13-14 (HRA ver. 1, vol. 1); Proclamations of Governor Hindmarsh, 28 December 1836, and Governor King, 592-93 (HRA ser. 1, vol. 3).

68. See, e.g., The King v. Murrell, (1836) Legge 72, 72 (Austl.). 
to the Crown. Even aliens ${ }^{69}$ engaging in unfriendly conduct ${ }^{70}$ are entitled to the Crown's protection. Consequently, act of state cannot be pleaded as a defense to actions brought by Aboriginal peoples in purportedly conquered lands. Whether a plaintiff is a subject or a resident alien, the plaintiff may not be barred from justice by the simple invocation of the act of state doctrine. ${ }^{71}$

It appears the common law courts also have some discretion as to whether they will apply the act of state doctrine when its prerequisites are met. It is submitted below that, when exercising its discretion, a court should conclude that it would be inappropriate for the doctrine to be invoked to bar a claim for Aboriginal sovereignty.

\section{United States Courts}

The act of state doctrine discussed above is peculiar to the common law courts. Unlike the Australian and English courts, the United States judiciary has shown a greater willingness to adjudicate matters pertaining to the legitimacy of the actions of state representatives. While these courts maintain that it would be inexpedient for them to pronounce upon certain political questions, the act of state doctrine as such has only been applied in limited circumstances.

Under the United States courts' conceptions, the act of state doctrine is seen as a principle of international law and practice designed to regulate relations between different nation-states. When applicable, it only prevents the courts of one country, for example the United States, from adjudicating a matter concerning the sovereign or state of another nation. The classic statement of this doctrine in Underhill $v$. Hernandez ${ }^{72}$ clearly sets out the rationale underlying the doctrine and its impact on judicial review:

Every sovereign State is bound to respect the independence of every other sovereign State, and the courts of one country will not sit in judgment on the acts of the government of another done within its own territory. Redress of grievances by reason of such acts must be obtained through the means open to be availed of by sovereign powers as between themselves. ${ }^{73}$

69. The word "aliens" refers to enemy aliens within Her Majesty's dominions who have obtained either expressly or implicitly license to live on Crown territory. See DE SMITH, supra note 43, at 438. "[T] his appears to cover all enemy aliens except combatants." Id.

70. For example, in Johnstone v. Pedlar, the plaintiff was arrested for subversive activities in Dublin. [1921] 2 App. Cas. 262 (1921) (appeal taken from Ir.)

71. See Nissan v. Att'y Gen., 2 All E.R. 1238, 1243 (C.A. 1967).

72. 168 U.S. 250,252 (1897).

73. Id. 
The United States courts have consistently reaffirmed this statement, ${ }^{74}$ declaring that the act of state doctrine is essentially a territorial limitation placed on the exercise of jurisdiction over foreign acts. ${ }^{75}$ The act of state doctrine would, therefore, be inapplicable to Aboriginal claims of sovereign and territorial rights. The adjudication of a dispute between a national and the government in the domestic courts does not fall within the perameters of the above-detailed rationale..$^{76}$

The doctrine was reworked in a series of cases concerning the Cuban expropriation of American assets, the leading case being Banco Nacional de Cuba v. Sabbatino." In essence, these cases have formulated a three-prong test to determine whether a court will consider a dispute involving a foreign nation. First, the court must consider whether there exists a codification or established consensus upon the relevant international law to be applied in the case. $^{78}$ The greater the codification or consensus, the more likely the matter will be heard, as this will enable the court to determine the dispute through the application of law rather than making a political judgment. ${ }^{79}$ The existence of settled legal principles with respect to Aboriginal sovereignty, delineated below, would therefore provide a strong factor in favor of a court exercising its jurisdiction over a dispute between an Aboriginal Nation and the occupying government. Second, the court must have regard for the impact the dispute may have on foreign relations. ${ }^{80}$ The "less important the implications of an issue are for . . . foreign relations, the weaker the justification for exclusivity in the political branches." 81 This factor would also suggest that a court could adjudicate a claim for Aboriginal sovereignty, as the dispute would not impact on foreign relations with other countries. ${ }^{82}$ Finally, the court must consider the status of the foreign government whose

74. See, e.g., Republic of Phillipines v. Marcos, 818 F.2d 1473, 1481 (9th Cir. 1987).

75. See American Banana Co. v. United Fruit Co., 213 U.S. 347, 356 (1909); Schooner Exchange v. M'Faddan, 11 U.S. (7 Cranch.) 116, 130 (1812).

76. Possibly such an adjudication would be relevant to an action brought by an Aboriginal claimant against the Australian government in the United States courts pursuant to the Alien Tort Statute.

77. 376 U.S. 398 (1964). As the court explained in Sabbatino, there is nothing inherent in the nature of sovereign authority, nor any principle of international law compelling the courts to adhere to the act of state doctrine. See id. at 423 . Rather, this practice rests on "constitutional underpinnings" governing the proper distribution of power among the branches of government. Id. See also First Nat'l City Bank v. Banco Nacional de Cuba, 406 U.S. 759 (1972); Forti v. Suarez-Mason, 672 F. Supp. 1531 (N.D. Cal. 1987); Fernandez v. Wilkinson, 505 F. Supp. 787 (D. Kan. 1980).

78. See First Nat'l City Bank, 376 U.S. at 428.

79. See id.

80. See id.

81. Id.

82. Similarly, in First Nat'l City Bank, three Justices in a five-Justice plural majority declined to apply the act of state doctrine, essentially because it believed that the adjudication would not interfere with the conduct of foreign relations. See id. 
actions are being reviewed. ${ }^{83}$ If a consideration of these factors suggests that the matter should be heard by the courts, then even the United States' narrow act of state doctrine will not prevent the matter from being heard.

In Forti v. Suarez-Mason, the court asserted that the nature of the breach was an additional factor to be taken into account in determining the applicability of the act of state doctrine. ${ }^{84}$ The Court stressed that while it may be appropriate to invoke the doctrine where there had been a breach of economic rights, it should not be invoked where "fundamental human rights lying at the very heart of the individual's existence" 85 have been violated, even if the acts were "encouraged or condoned by states." ${ }^{86}$ Thus, an encroachment upon an individual's, or sub-state collective's, human rights lies outside the protective shield the doctrine offers the government. ${ }^{87}$ Moreover, Aboriginal claims for sovereign and territorial rights would fall into the category of claims which should not be barred by the act of state doctrine, particularly in light of international law's concern for the promotion of the decolonization of post-colonial states and the selfdetermination of indigenous peoples. ${ }^{88}$

In addition to the above-detailed limitations upon the scope of the doctrine, the party seeking to convince the court as to its applicability bears a heavy burden of proof. ${ }^{89}$ Allegations of official conduct do not automatically trigger the availability of the act of state doctrine. ${ }^{90}$ The defendant must satisfy a threshold requirement before the court will even consider the Sabbatino factors. ${ }^{91}$ It must be established that the facts show "that an Act of State has occurred, coupled with a legal showing that no bar to the doctrine is applicable under the factual circumstances." then that the court will even consider applying the defense.

\section{Judicial Discretion}

Finally, it appears that United States courts have discretion in deciding whether or not to apply the act of state doctrine. An "act of state" is not an

83. See id.

84. See Forti v. Suarez-Mason, 672 F. Supp. 1531, 1546 (N.D. Cal. 1987). Cf. Fernandez v. Wilkinson, 505 F. Supp. 787, 799-800 (D. Kan. 1980) (discussing the unsustainability of government action violating fundamental human rights but not specifically addressing the act of state doctrine).

85. Forti, 672 F. Supp. at 1546.

86. Id.

87. See id. at $1546-47$.

88. See United Nations international instruments cited supra note 2.

89. See Alfred Dunhill of London, Inc. v. Republic of Cuba, 425 U.S. 682, 694-95 (1976); Republic of Philippines v. Marcos, 818 F.2d 1473, 1481-88 (9th Cir. 1987); Forti, 672 F. Supp. at 1544-47.

90. See Forti, 672 F. Supp. at 1546.

91. See id. at 1546 n.9.

92. Ramirez de Arellano v. Weinberger, 745 F.2d 1500, 1534 (D.C. Cir. 1984). 
absolute jurisdictional bar. It is only respected out of comity, ${ }^{93}$ and there are many examples of courts exercising jurisdiction over a foreign sovereign despite the act of state doctrine. ${ }^{94}$

The court's discretion to reject the act of state doctrine would be appropriately exercised in the case of a claim for Aboriginal sovereign rights. This is supported by the court's emphasis in Forti v. Suarez-Mason ${ }^{95}$ that the act of state doctrine should not be applied to cases involving "fundamental human rights lying at the very heart of the individual's existence." $"$ As Aboriginal sovereignty is entwined with human rights, such as cultural, political and territorial integrity, it is contended that it would be appropriate for a court to refuse to apply the act of state doctrine to a claim for sovereign rights.

This discretion is equally applicable to courts applying the common law. To this end it has been suggested that the High Court of Australia "might consider the exercises of prerogative by which Australia was acquired for the British Crown to be judicially reviewable on broad public policy grounds." $"$ In Mabo v. Queensland, the Court recognized that where old common law doctrines seriously offend modern values, a question becomes apparent on whether the doctrine should be sustained and applied. ${ }^{98}$ It is submitted that applying the act of state doctrine to bar a claim to Aboriginal sovereignty would offend contemporary values which are reflected in current moves toward decolonization and self-determination ${ }^{99}$ for indigenous peoples. ${ }^{100}$

The High Court of Australia also recognized that international law was a "legitimate and important influence on the development of the common law, especially when international law declares the existence of universal

93. See Verlinden v. Central Bank of Nigeria, 461 U.S. 480, 486 (1983). See generally First Nat'I City Bank v. Banco Nat'l de Cuba, 406 U.S. 75 (1972).

94. See, e.g., The Lantissina Irivdad, 20 U.S. (7 Wheat.) 283, 354 (1822); Filartiga v. Pena-Irala, 630 F.2d 876, 889-90 (2d Cir. 1980); Forti, 672 F. Supp. at 1535; Fernandez v. Wilkinson, 505 F. Supp. 787, 799-800 (D. Kan. 1980).

95. 672 F. Supp. at 1549. See also Fernandez, 505 F. Supp. at 799-800.

96. Forti, 672 F. Supp. at 1549.

97. See Mitchell v. Director of Public Prosecutions [1986] L.R.C. Const. 35, 40 (Gren.). See also S. Gray, Planting the Flag or Burying the Hatchet: Sovereignty and the High Court Decision in Mabo v. Queensland, 2 GRIFFITH L. REV. 39, 47 (1993) (arguing that the annexation of Australia constituted a "revolution" and the common law courts have jurisdiction to adjudicate on the validity of a revolution). See also Madzimbamuto v. LardnerBurke [1966] R.L.R. 756 (Rhodesia Gen. Div.); [1968] (2) SALR 284 (S. Afr.); R. W. M. Dias, Legal Politics: Norms Behind the Grundnorm, 26 CAMBRIDGE L.J. 233 (1968); J. W. Harris, When and Why Does the Grundnorm Change?, 29 CAMBRIDGE L.J. 103 (1971).

98. See Mabo v. Queensland (1992) 175 C.L.R. 1, 29, 30 (Austl.). Ironically, this was one of the Australian cases where the act of state doctrine was used to deny a consideration of the legitimacy of the annexation of Australia. Cf. discussion supra note 26 (describing long-standing claims of Aboriginal sovereignty).

99. See discussion supra note 2.

100. See Gray supra note 97 , at 47-48. 
human rights. A common law doctrine founded on unjust discrimination in the enjoyment of civil and political rights demands reconsideration." 101 As submitted above, a claim for Aboriginal sovereignty involves the recognition and respect of human rights, such as Aboriginal cultural, as well as political and territorial integrity. Accordingly, if the act of state doctrine undermines these rights, then it "demands reconsideration." 102

Particularly, when a real dispute is brought before a court, ${ }^{103}$ it would be inappropriate for the political nature of the underlying issue to be used to bar its consideration. ${ }^{104}$ The courts are duty-bound to pronounce upon suits brought before them by parties with the requisite standing. The courts provide an important check on the arbitrary use of governmental and executive powers, and this responsibility would not be discharged should courts refuse to entertain actions which recognize and enforce the rights of Aboriginal peoples. The courts' responsibilities should not be shirked under the guise of nonjusticiability.

Thus, the act of state doctrine will not necessarily bar a claim for Aboriginal sovereignty being litigated in the municipal courts, and certainly would not prevent claims from being made in an appropriate international forum.

\section{Acquisition of Sovereignty by Prescription}

\section{Introduction}

Prescription $^{105}$ is a dubious ${ }^{106}$ method of acquiring territory that is said

101. Mabo, (1992) 175 C.L.R. at 25, 41, 42, 58.

102. See Gray, supra note 97 , at 50.

103. For example, if an Aboriginal person was charged with a criminal offense, or involved in civil action and denied the court's jurisdiction to hear the matter, as in The King v. Murrell, (1836) Legge 72 (Austl.), and In re Phillips (1987) 72 A.L.R. 508 (Austl.), the dispute would involve a consideration of the legitimacy of the "occupying" state's claims to sovereignty and the existence of any Aboriginal sovereign rights.

104. It has been suggested that compellability, rather than the political nature of the dispute, is the only criteria by which a matter must be determined. See generally Melbourne Corp. v. Commonwealth (1947) 74 C.L.R. 31 (Austl.). Similarly, one of the most authoritative constitutional law theorists, A. V. Dicey asserted that Parliament's sovereignty is a question of law, rather than a political issue, that is to be determined by the courts. See A. V. DiceY, InTROduction to THE STUdy OF THE LAW OF THE CONSTITUTION 70-85 (1959).

105. A comprehensive discussion of this notion is beyond the scope of this article. For further discussion of prescription, see Cassidy, supra note 3, ch. 24.

106. There are, for example, no instances of any international tribunal conclusively supporting the doctrine of prescription. While some have suggested that the Island of Palmas supports its existence, acquisitive prescription was not the basis of Arbitrator Max Huber's award. See generally Island of Palmas, 22 AM. J. INT'L L. 867 (1928). The matter essentially involved a consideration of the respective claims of the Netherlands and the United States governments to sovereignty over the Island of Palmas. See id. Thus, it was a case of 
to allow a de facto government to remove defects in its putative title when the prior sovereign has consented or acquiesced to the usurping of its sovereignty. As Brownlie notes, the "apology" for the notion lies in considerations of "good faith, the presumed voluntary abandonment of rights by the party losing title, and the need to preserve international order and stability." 107

Prescription has also been used in Australia to refute the legitimacy of claims of Aboriginal sovereignty. The Senate Standing Committee on Constitutional and Legal Affairs, for example, declared that the Commonwealth government could invoke the doctrine of prescription to remedy any defect in its sovereign title. ${ }^{108}$ The Committee asserted that a prescriptive title arises when no clear title to sovereignty could "be shown by way of occupation conquest or cession, but the territory in question had remained under the continuous and undisputed sovereignty of the claimant for so long that the position had become part of the established international order of nations." 109 It was suggested that this principle was applicable to the Australian circumstances and that with the passage of time and the implied acquiescence of the dispossessed sovereign, a prescriptive title was acquired by the "invading" sovereign. ${ }^{10}$

In this manner, despite the operation of the intertemporal rule, ${ }^{11}$ it has been suggested that any possible illegality underlying the acquisition of sovereignty is irrelevant. Even if an acquisition was contrary to international law, it is suggested that through the doctrine of prescription, the "occupying" state has effectively derogated from Aboriginal sovereign and territorial rights, ultimately obtaining the legitimate title to the subject lands. Underlying this method of territorial acquisition is the belief that "a state which has slept upon its rights" ${ }^{\prime \prime 2}$ should not be able to revive them to defeat

competing contemporaneous claims of sovereignty, rather than "true" prescription where the prior sovereign acquiesces. See id. Huber was not dealing with an imperial power seeking to legitimate its purported acquisition of Aboriginal lands. Cf. BROWNLIE, supra note 49, at 162. Further, there is nothing to suggest Huber believed either competing power had acquired full sovereign rights to the lands in dispute. He was only concerned with deciding between the rival claims and it is possible neither party satisfied the theoretical requirements for the acquisition of territory. The Netherlands government's claim to sovereignty was ultimately founded upon the country's peaceful and continuous display of state authority. Similarily, in Legal Status of Eastern Greenland (Den. v. Nor.), the court held that, provided the other competing State could not make out a superior claim, Denmark had the right to the subject territory even though Denmark demonstrated "very little in the way of . . . [an actual exercise] of sovereign rights." 1933 P.C.I.J. (Ser. A/B) No. 53, at 45.

107. BROWNLIE, supra note 49 , at 157.

108. See StANding CommitTEe, supra note $26,13.37$.

109. Id.

110. See id.

111. The intertemporal rule requires the validity of certain rights be determined in light of modern developments in international law, rather than the law prevailing at the time of the initial act in dispute.

112. D. W. Greig, INTERNATIONAL LAW 163 (2d ed. 1976). 
a state which has constantly exercised sovereign rights for a lengthy period.

While the doctrine of prescription may at first glance appear to be simple, it entails a number of prerequisites which those who seek to utilize the doctrine to bar claims of Aboriginal sovereignty fail to grasp. Therefore, if the doctrine is recognized under international law, these prerequisites would prevent the denial of Aboriginal sovereignty under the guise of prescription. However, as discussed earlier, even the doctrine of prescription has been highly debated. ${ }^{113}$

\section{Prescription under International Law}

Given that prescription has its source in the works of jurists, rather than case law or treaties, it is not surprising that there are conflicting notions of precisely what the concept entails and what the prerequisites are for creating a prescriptive title within each of these doctrines. ${ }^{114}$ However, Brownlie ${ }^{115}$ suggests a compilation of the conditions required for acquisitive prescription, which would appear to be correct, if the doctrine exists in international law today.

113. A number of jurists have criticized the rule and questioned its validity in the international legal system. See, e.g., Hugo Grotius, The Freedom of the SeAS (MARE LIBERUM) 47 (Ralph Van Deman Magoffin ed. \& trans., 1916) (1605) (condemning prescription as the "last defense of injustice"). "Prescription is a matter of municipal law; hence it cannot be applied as between kings, or as between free and independent nations." Id. (footnote omitted). Similarly, in Concerning Right of Passage Over Indian Territory (Port. $v$. India), Judge Mareno Quintaria declared acquisitive prescription to be "a private law institution which I consider finds no place in international law." 1960 I.C.J. 6, 88 (Apr. 12) (dissenting opinion of Judge Mareno Quintaria). See also U.N. Survey of International Law in Relation to the Work of Codification of the International Law Commission: Memoranda by the Secretary-General, U.N. International Law Commission, at 39, U.N. Doc. A/CN.4/1/Rev.1 (1949). Further, the doctrine is contrary to other established rules of international law. Mere silence, for example, has never been enough to divest a state of its title. See generally Concerning Sovereignty Over Certain Frontier Lands (Belg. v. Neth.), 1959 I.C.J. 209 (June 20).

114. The doctrine is regarded by jurists as having three forms:

1. Immemorial possession. This is understood to give title when a state of affairs exists the origin of which is uncertain and may have been legal or illegal but is presumed to be legal.

2. Prescription under conditions similar to those required for usucapio in Roman law: uninterrupted possession, justus titulus even if it were defective, good faith, and the continuance of possession for a period defined by the law. 3. Usucapio, modified and applying under conditions of bad faith. Thus Hall, Oppenheim, and Fauchille do not require good faith in the context of international law.

BROWNLIE, supra note 49 , at $157-58$. With respect to the first category, it is not actually a form of prescriptive title as there has been no acquiescence by the prior sovereign. As to the third category, the use of force is not an acceptable basis for conferring on an occupying state a prescriptive title.

115. See id. at 159-62. 
First, possession must be exercised a titre de souverain. There must be a display of state authority and the absence of recognition of sovereignty in another state. Except in the case of contemporaneous competitive acts of sovereignty, the first condition requires acquiescence ${ }^{116}$ by the former sovereign. In the present context, it is submitted that international law recognizes both Aboriginal occupation ${ }^{117}$ and Aboriginal sovereignty ${ }^{118}$ and that Aboriginal sovereignty has never been ceded to the "occupying" states. ${ }^{119}$ The absence of any such acquiescence is evidenced by the Aboriginal resistance to "white" settlement ${ }^{120}$ and modern day ${ }^{121}$ displays of discontent with the "occupying" government. ${ }^{122}$ Members of Aboriginal communities still dispute the legality of the controlling government's authority, ${ }^{123}$ rebuking any suggestion of acquiescence to the "new" sovereign power. Hence, the first element of prescription would not be satisfied in the subject cases.

Second, possession must be peaceful and uninterrupted. ${ }^{124}$ Once it is accepted that the sovereign rights to the countries under consideration

116. As Brownlie noted, some writers, such as Hall, Moore, Hyde and Guggenheim suggest acquiescence is no longer required. See generally BROWNLIE, supra note 49. They argue a prescriptive title can be obtained simply with the lapse of time, supported by possession of the relevant land. See generally id. These opinions are neither sustained by state practice nor jurisprudence and cannot, therefore, be relied upon as authoritative. See generally id. Brownlie notes that these jurists seem uncertain about the matter, since their views are ambiguous and inconsistent on this point. See generally id.

117. The recognition of Aboriginal occupation prevents lands from legally being terra nullius (i.e., open to acquisition by mere occupation). See Western Sahara, 1975 I.C.J. 12, 123 (Oct. 16) (separate opinion of Judge Dillard).

118. See generally id.

119. See discussion supra notes 26,64 .

120. Contrary to the traditional picture painted of the annexation of Australia, the Aboriginal occupants resisted the occupation of Australia and at times did so very effectively. See generally NoEl LOOS, INVASION AND RESISTANCE: ABORIGINAL-EUROPEAN RELATIONS ON THE NORTH QUEENSLAND FRONTIER, 1861-1897 (1982); HENRY REYNOLDS, THE OTHER SIDE OF THE FRONTIER: ABORIGINAL RESISTANCE TO THE EUROPEAN INVASION OF AUSTRALIA (1982); Julie Cassidy, The Conquered Continent, chs. 5-6 \& app. 8 (1986) (unpublished Honors thesis, University of Adelaide, Faculty of Law, Adelaide, South Australia, Australia) (on file with author) [hereinafter Cassidy, The Conquered Continent]; Julie Cassidy, Aboriginal Resistance in South Australia (unpublished research paper) (on file with author).

121. For example, in July 1990, hundreds of police officers from the Surete du Québec, the provincial police force, sought to disband the Mohawk Nation's blockade in Oka, Québec. See Daniel Lavery \& Brad Morse, The Incident at Oka: Canadian Aboriginal Issues Move to the Front Burner, 48 ABORIGINAL L. BULL. 6 (1991).

122. In Australia, the alienation Aboriginal people feel towards the Australian government is evidenced by the Aboriginal Embassy that was set up on the lawns of the then Parliament House in Australia in 1972 and the occupation of that building as an Aboriginal embassy on January 27, 1992. As noted previously, in July 1990, members of the Australian Aboriginal community established an Aboriginal Provisional Government representing the Aboriginal peoples' claims to their sovereign rights. See discussion supra note 26.

123. See discussion supra note 64.

124. See generally Island of Palmas, 22 AM. J. INT'L L. 867 (1928). 
originally resided in the Aboriginal occupants, the second element is refuted by an acknowledgment of the above-mentioned acts of Aboriginal resistance ${ }^{125}$ and discontent. ${ }^{126}$ This view is supported by the decision in the Chamizal Arbitration. ${ }^{127}$ There, the United States government's claim to a tract of the Rio Grande on the basis of prescription failed because its possession had not been without challenge. If the diplomatic protests in this case sufficed to prevent a prescriptive title being acquired, Aboriginal resistance ${ }^{128}$ would certainly prevent such a title from being acquired. ${ }^{129}$

Third, the possession must be public. This requirement flows from the need for acquiescence on the part of the previous sovereign. ${ }^{130}$ The sovereign can only acquiesce to claims of which it has knowledge.

Finally, possession must persist. The most uncertain aspect of the international doctrine of prescription is the question of "how long must the possession persist?" Older authorities insisted upon immemorial possession, while other writers specified requisite fixed periods. ${ }^{131}$ Most modern commentators, however, believe the length of time required varies depending upon the particular circumstances of each case. ${ }^{132}$ If this is so, "time" as such is not really a special prerequisite for a prescriptive title. ${ }^{133}$

Some jurists, such as Oppenheim, allowed prescriptive titles to be acquired even when they originated out of force. ${ }^{134}$ Such a suggestion

125. See discussion supra notes 26,64 .

126. See discussion supra notes 24, 64, 122.

127. The Chamizal Arbitration Between the United States and Mexico, reprinted in 5 AM. J. INT'L L. 782, 805-07 (1911) [hereinafter The Chazimal Arbitration].

128. Additionally, it should be noted that modern international law prohibits the use of force to settle international disputes. See U.N. ChARTER art. 2, 11 3-4.

129. The failure of Aboriginal peoples in the Chamizal Arbitration to use the United Nations or the International Court of Justice to resolve this territorial dispute and regain their territory should not bar them from denying the acquisition of a prescriptive title to their lands to these post-colonial powers. See BrownLIE, supra note 49, at 161. In Minquiers and Ecrehos, the United Kingdom argued French protests were ineffective because they should have been supported by pressure to have the matter referred to an international tribunal. See Minquiers and Ecrehos (Fr. v. U.K.), 1953 I.C.J. 47 (Nov. 17). While this view was largely accepted by Judge Carneiro, it was required by treaty that both States were bound to have legal disputes settled by the Permanent Court of Arbitration. See id. at 106-08 (individual opinion of Judge Levi Corneiro).

130. Where, however, the dispute is based on contemporaneous competing state activity, knowledge is more likely to be assumed and publicity will not be as important. In such cases the question of acquiescence is only of minor relevance, for the dispute is normally decided on the relative strength of the contemporaneous claims of the competing powers.

131. See David Dudley Field, Outlines of an InTernational Code, I 52 (2d ed. 1876). Uninterupted possession of fifty years by à nation will exclude the claim of any other nation. See id.

132. See 1 PaUl Fauchille, Traité de Droit InTERnational PUblic, pt. 2, at 762 (1925); 1 OPPENHEIM, supra note 3, at 577-78 (1955).

133. BROWNLIE, supra note 49 , at 161-62.

134. See GREIG, supra note 112, at 166 . Oppenheim used the notion of prescription in the widest possible manner. See, e.g., OPPENHEIM, supra note 3, at 576. 
ignores the requirements that the prior sovereign acquiesce to the "new" state and that the latter's possession must be peaceful. Moreover, an illegal act of force should not be legitimated in this manner by the mere passage of time. It is inappropriate for the doctrine of prescription ${ }^{135}$ to create rights and title out of possession based on illegal acts. In this context it is pertinent to note the comments of Vice-President Ammoun in Namibia:

[W] hile the law of former times ... tolerated conquest and annexation, of which South Africa's conduct appears to be one of the last examples, modern law . . . condemns them beyond reprieve. Annexation is nothing less than the negation of the new law of self-determination. Thus the United Nations has reiterated that acquisition of a territory may not be effected by the use or the threat of force. Nonetheless, South Africa has throughout, and even before the Court, sought to justify its continued occupation of Namibia by claiming to be there by right of conquest or by the effect of acquisitive prescription. The Court has dismissed this claim. ${ }^{136}$

Thus, "occupying" states cannot rely on their illegitimate acts of forceful dispossession to invoke a prescriptive title in a manner designed to deny Aboriginal sovereign claims. That people have long been displaced or oppressed does not convert a lawless act into a lawful one. ${ }^{137}$ Pertinent to this point is the fact that while peaceful occupation might bar subsequent attempts at colonization by other European powers, ${ }^{138}$ it has never been considered grounds for extinguishing the rights of the indigenous inhabitants. ${ }^{139}$

For the reasons suggested above, it is submitted that if international law recognizes acquisitive prescription, ${ }^{140}$ the doctrine has a limited scope and, in accordance with the sentiments expressed in Namibia, could not be used by the subject "occupying" states to legitimize dispossessing the Aboriginal occupants. ${ }^{141}$ An examination of the doctrine only serves to bolster the claims of the Aboriginal occupants to their sovereign and territorial rights.

135. Greig believes that the cases to which Oppenheim refers are cases of historical consolidation, rather than prescription. See GREIG, supra note 112, at 166.

136. Namibia, 1971 I.C.J. 16, 91 (June 21) (separate opinion of Vice-President Ammoun).

137. The International Court of Justice has taken the view that self-determination superseded a state's.historical claim to territorial rights. See generally Western Sahara, 1975 I.C.J. 12 (Oct. 16).

138. See generally The Chamizal Arbitration, 5 AM. J. INT'L L. 782 (1911).

139. See Concerning Right of Passage Over Indian Territory (Port. v. India), 1960 I.C.J. 6, 38 (Apr. 12). See generally Legal Status of Eastern Greenland (Den. v. Nor.), 1933 P.C.I.J. (ser. A/B) No. 53 (Apr. 5).

140. See discussion supra notes $103,108$.

141. Namibia, 1971 I.C.J. at 91 (separate opinion of Vice-President Ammoun). 
Unlike the "occupying" states, they can prove immemorial possession. Moreover, even if the doctrine of prescription could be manipulated to support an "occupying" state's claim to sovereign title, the relevant international laws recognize that Aboriginal sovereignty and territorial rights are norms of jus cogens; ${ }^{142}$ therefore, the "occupying" state's prescriptive title is irrelevant. The prescriptive title of an occupying state does not provide a defense for a failure to recognize the legal rights of Aboriginal peoples. ${ }^{143}$ Given that the doctrine has no established legal basis, ${ }^{144}$ it is unfortunate that "occupying" states such as Australia should seek to utilize such a dubious doctrine to mislead Aboriginal claimants as to the strength of their claims.

Provided that the bars to Aboriginal claims to sovereignty can be dismissed in the manner suggested above, it is now pertinent to consider recognition of Aboriginal sovereignty under international law.

\section{AbORIGINAL SOVEREIGNTY IN INTERNATIONAL LAW}

\section{A. Terra Nullius}

Central to the existence of Aboriginal sovereign rights today is the validity of the purported acquisition of these peoples' traditional lands by imperial and colonial powers. While historically, unoccupied territory, also known as terra nullius, could be acquired by discovery and effective occupation, ${ }^{145}$ inhabited land could only be acquired by descent, conquest, ${ }^{146}$ cession, or perhaps prescription. ${ }^{147}$ The historical treatment of the Aboriginal peoples of Africa, Australia and North America directly relates to the erroneous classification of their lands as terra nullius, ${ }^{148}$ or declared

142. These are nonderogable norms essential to the maintenance of the international legal order, where prescription cannot validate a breach of the rule of jus cogens. See id. at 89-90.

143. See BROWNLIE, supra note 49 , at 501.

144. See discussion supra notes $106,113$.

145. While it has been suggested that in the eighth century mere discovery was sufficient to establish title terra nullius, the inchoate title stemming from discovery had to be perfected by effective occupation. See generally Island of Palmas, 22 AM. J. INT'L L. 867, 872-73 (1928).

146. For a discussion of the arguments that would suggest that Australia was acquired by conquest, rather than settlement, see Cassidy, The Conquered Continent, supra note 120, chs. 5-6 \& app. 8. This may be relevant to preserving Aboriginal rights as, at common law, in a conquered country the private rights of the original occupants continue unaffected until expressly abrogated by the conquering power. See generally Anonymous, 24 Eng. Rep. 646 (Ch. 1722); Blankard v. Galdy, 91 Eng. Rep. 356 (K.B. 1693). See generally Julie Cassidy, The Significance of the Classification of a Colonial Acquisition: The Conquered/Settled Distinction (unpublished manuscript) (on file with author).

147. See discussion supra Part II(C)(2) (discussing the dubious doctrine of prescription).

148. See The Queen v. Van Der Peet [1996] 137 D.L.R. 4th 289, 380 (Can.). Cf. Asch, supra note 26; Slattery, supra note 25 , at $685-91$. 
open for discovery and settlement. ${ }^{149}$ Thus, in Australia, until very recently, ${ }^{150}$ the denial of Aboriginal sovereignty was based on the false notion that the continent was terra nullius and was acquired by peaceful occupation. ${ }^{151}$ Through such classification of the continent and its occupants, the imperial authorities avoided the difficulties involved in acquiring or supplanting Aboriginal sovereignty.

It is, however, most important to be a valid occupation that the land be terra nullius. ${ }^{152}$ Thus, the initial ${ }^{153}$ and continued ${ }^{154}$ validity of colonial acquisitions and the survival of Aboriginal sovereignty in the countries under consideration will depend upon whether Aboriginal occupation was recognized by international law as preventing land from being classified as terra nullius.

One of the most respected works dealing with this question is Lindley's The Acquisition and Government of Backward Territory in International Law. ${ }^{155}$ Lindley reviewed the opinions of jurists over the centuries and

149. See Van der Peet, 137 D.L.R. 4th at 330. See also Milirrpum v. Nabalco Party Ltd. (1971) 17 F.L.R. 141 (Austl.); Cooper v. Stuart, 14 App. Cas. 286, 291-94 (P.C. 1889) (appeal taken from N.S.W.). Cf. M. N. SHAW, TITLE to TERRITORY IN AFrICA: INTERNATIONAL LEGAL ISSUES 31-38 (1986); Brad Berg, Introduction to Aboriginal Selfgovernment in International Law: An Overview, 56 SASK. L. REV. 375, 382-83 (1992).

150. That Australia was terra nullius was finally rejected in Mabo v. Queensland (1992) 175 C.L.R. 1, 33, 40-42, 58, 181-82 (Austl.). However, the High Court in Mabo upheld the settled classification of the annexation of Australia. See id. at 33, 180. The court drew a distinction between whether the Crown had acquired sovereign title to Australia and whether it had acquired beneficial title to Aboriginal lands. See id. at 32, 44-45, 48, 180. Thus, Justice Toohey asserted that in considering the consequences of the annexation of Australia "the distinction between sovereignty and title to rights in the land is crucial." Id. at 180. This allowed the Court to start with the premise that the "Imperial Crown acquired sovereignty [over Queensland] on 1 August 1879" and merely considered whether "the Crown also acquired absolute beneficial ownership of the land ... when the Crown acquired sovereignty." Id. at 32 .

151. See generally Milirrpum v. Nabalco Party Ltd. (1971) 17 F.L.R. 141 (Austl.); Cooper v. Stuart, 14 App. Cas. 286 (P.C. 1889) (appeal taken from N.S.W.). The view that Canada was also acquired through discovery and settlement was recently affirmed in Calder. See Calder v. Attorney-General of British Columbia [1973] S.C.R. 313, 328-29, 383, 401-02 (Can.). See also The Queen v. Van der Peet [1996] 137 D.L.R. 4th 289 (Can.); The Queen v. Sparrow [1990] 70 D.L.R. 385, 401, 404 (Can.). For a discussion of the acquisition of the United States, see generally Johnson v. M'Intosh, 21 U.S. (8 Wheat.) 543 (1823).

152. GROTIUS, supra note 113 , at 13.

153. If it were established that an international custom recognizing Aboriginal sovereign and territorial rights was a rule of $j u s$ cogens, it may retroactively impair these colonial titles in so far as they are inconsistent with the terms of the custom.

154. The intertemporal rule requires international rights, such as sovereignty, that are perpetually exercised in conformance with international law as it develops. Thus, the validity of an acquisition of sovereign rights must comply with international law at the time of the dispute.

155. See generally MARK F. LINDLEY, THE ACQUISITION AND GOVERNMENT OF BACKWARD TERRITORY IN INTERNATIONAL LAW (Negro Universities Press 1969) (1926). 
found:

[A] persistent preponderance of juristic opinion in favour of the proposition that lands in the possession of any backward peoples who are politically organized ought not to be regarded as if they belonged to no one. . . . [W] [Werever a country is inhabited by people who are connected by some political organization, however primitive and crude, such a country is not to be regarded as territorium nullius and open to acquisition by Occupation. . . . ${ }^{156}$

Lindley further states:

[I]n order that an area shall not be territorium nullius, it would appear . . . that it be inhabited by a political society, that is, by a considerable number of persons who are permanently united by habitual obedience to a certain and common superior, or whose conduct in regard to their mutual relations habitually conforms to recognized standards. ${ }^{157}$

Thus, all that international law required before Aboriginal populations could be recognized as being in occupation of land was a degree of political organization and authority sufficient for the general maintenance of order. ${ }^{158}$

Particularly, given Lindley's comment that "[n]o race is without organization of some kind," 159 the Aboriginal peoples of Australia and North America satisfied these international requirements and their occupation prevented their lands from being terra nullius. While most of these Aboriginal Nations did not conform with eurocentric political systems, ${ }^{160}$ each had sophisticated legal systems which had to be obeyed under the threat of sanction. Their lives were highly regulated by social rules providing "a

156. Id. at 17-20.

157. Id. at 22-23. While the writers of the late nineteenth century applied more stringent tests, they also believed that Aboriginal sovereignty precluded land from being acquired by occupation. See id. at 18. Westlake, for example, wrote "an uncivilized tribe [could] grant by treaty such rights as it understands and exercises." JOHN WESTLAKE, THE COLLECTED PAPERS ON INTERNATIONAL LAW 151 (L. Oppenheim ed., 1911).

158. Note, some international law jurists believed occupation of lands by Aboriginal peoples did not prevent land being characterized as terra nullius. See generally ALPHONSE RIVIER, PRINCIPES DU DROIT DES GENS (1896). This view continues to be held by some modern scholars. See L. C. Green, Claims to Territory in Colonial America, in THE LAW of NATIONS AND THE NEW WORLD 125-26 (L. C. Green \& O. P. Dickson eds., 1989).

159. LINDLEY, supra note 155 , at 19.

160. It is possible that certain peoples of South Australia and the Maori peoples of New Zealand would have satisfied these models. See generally Taplin, The Ngarrindjeri, in THE NATIVE TRibes OF SOUTH Australia (J. D. Woods, ed., 1879). 
stable order of society" within the above test. ${ }^{161}$ As Justice Blackburn declared in Milirrpum v. Nabalco with respect to the Aboriginal peoples of Australia, "[i]f ever a system could be called 'a government of laws, and not of men,' it is shown in the evidence before me." 162 Consequently, the Aboriginal lands purportedly acquired by colonial forces were not uninhabited terra nullius that were acquired by "peaceful" occupation. ${ }^{163}$

Lindley's analysis is supported by the International Court of Justice's advisory opinion in Western Sahara. ${ }^{164}$ The court delivered an advisory opinion on two matters relating to the Spanish colonization of the Western Sahara. ${ }^{165}$ One of the questions involved was determining whether the Western Sahara was a territory belonging to no one (terra nullius) in 1884 when colonized by the Spanish. The majority of the court held that as the subject lands were inhabited by nomadic tribes, they could not be classified as terra nullius, and stated that "[w]hatever differences of opinion there may have been among jurists, the State practice of the relevant period indicates that territories inhabited by tribes or peoples having a social and political organization were not regarded as terra nullius." 166 As Judge Gros stressed, "[T]he independent tribes travelling over the territory, or stopping in certain places, exercised a de facto authority which was sufficiently recognized for there to have been no terra nullius." 167 Vice-President Ammoun noted in the course of his judgment:

Mr. Bayona-Ba-Meya goes on to dismiss the materialistic concept of terra nullius, which led to this dismemberment of Africa following the Berlin Conference of 1885. Mr. BayonaBa-Meya substitutes for this a spiritual notion: the ancestral tie between the land, or "mother nature", [sic] and the man who was born therefrom, remains attached thereto, and must one day return thither to be united with his ancestors. This link is the basis of the ownership of the soil, or better, of sovereignty. ${ }^{168}$

While the word "occupation" was at times used to signify the acquisition of sovereignty from these peoples, the majority of the Court asserted that this

161. Milirrpum v. Nabalco Party Ltd. (1971) 17 F.L.R. 141, 267 (Austl.). See also Kenneth Maddock, Aboriginal Customary Law, in ABORIGINES AND THE LAW 212 (Peter Hanks and Bryan Keon-Cohen eds., 1984).

162. 17 F.L.R. at 267.

163. For a more complete discussion of whether Australia was a terra nullius territory, see Cassidy, The Conquered Continent, supra note 120, chs. 4-5.

164. 1975 I.C.J. 12 (Oct. 16).

165. The advisory opinion was requested by the General Assembly of the United Nations. See id.

166. Id. at 39 .

167. Id. at 75 (declaration of Judge Gros).

168. Id. at 85-86 (separate opinion of Vice-President Ammoun). 
use of the term was technically improper. ${ }^{169}$ An original sovereign title could only be acquired by occupation of terra nullius. If land was not terra nullius, only a derivative title could be acquired and only through agreements with local rulers. These sentiments were approved or substantially adopted by Judges Dillard, de Castro and Boni. ${ }^{170}$

Given the International Court of Justice's implicit refutation of the "cultivation test" ${ }^{171}$ and the need for Aboriginal societies to comply with European-like forms of government ${ }^{172}$ before their lands could be placed outside the category of terra nullius, it is again submitted that the lands of the subject Aboriginal peoples were not terra nullius. The required "social and political organization" existed, and, as is apparent from Western Sahara, the nomadic nature of some of these peoples' occupation did not prevent them from exercising sovereignty over their lands. ${ }^{173}$ Vice-President Ammoun's comments regarding the relationship the peoples of the Western Sahara have with their land echo that of the subject Aboriginal peoples. ${ }^{174}$ Moreover, in light of Judge Dillard's comment that "you do not protect a terra nullius," 175 Aboriginal resistance to colonial expansion also appears to be important to the classification of land. ${ }^{176}$

169. See id. at $39-40$.

170. See id. at 124, 171, 173 (separate opinions of Judges Dillard, de Castro, and Judge ad hoc Boni).

171. It is questionable whether authorities such as Blackstone and Vattel believed the failure to cultivate land amounted to a forfeiture of the rights of possession. See Cassidy, The Conquered Continent, supra note 120, chs. 3-4. However, Australian courts and the Privy Council, until most recently, believed lands occupied by non-cultivating peoples to be terra nullius. See Cooper v. Stuart [1889] 14 App. Cas. 286, $291-94$ (P.C. 1986) (appeal taken from N.S.W.S. Ct.). See also Coe v. Commonwealth (1979) 53 A.L.J.R. 403 (Austrl.); Milirrpum v. Nabalco Party Ltd. \& the Commonwealth (1971) 17 F.L.R. 141 (Austrl.).

172. See Coe, 53 A.L.J.R at 407. Justice Gibbs applied an extremely eurocentric test requiring distinct legislative, executive and judicial organs before recognizing a peoples as being capable of possessing any sovereignty. He also required the judicial organs to apply law of a European type. While Justice Blackburn in Milirrpum, 17 F.L.R. at 161, warned against applying eurocentric notions to Aboriginal peoples and consequently held that Aboriginal society did not have to conform with European models of law making and enforcement, later in his judgment he ignored his own warning and required the claimants establish a proprietary interest in their lands.

173. See generally Western Sahara, 1975 I.C.J. 12 (Oct. 16).

174. See Milirrpum, 17 F.L.R. at 141; In re Kearney (1984) 52 A.L.J.R. 31 (Austrl.); Ex parte Japanangka (1984) 52 A.L.R. 31 (Austrl.) (discussing the Aboriginal relationship with land). See generally ABORIGINAL LEGAL IsSUES (McRae et al. eds., 1991).

175. Western Sahara, 1975 I.C.J. 12, 124 (Oct. 16) (emphasis added).

176. See generally Cassidy, The Conquered Continent, supra note 120. 


\section{B. Sovereign Aboriginal Communities}

\section{Sovereign Entities}

While Aboriginal occupation prevents land from being classified as terra nullius, thereby undermining the validity of "white" occupation of countries such as Australia, it is still debatable whether international law recognized such occupation as giving rise to sovereign rights. A survey of international law jurists again reveals that the preponderance of thought was that "the aborigines undoubtedly had true dominion in both public and private matters." 177 They believed "neither their princes nor private persons could be despoiled of their property on the ground of them not being true owners." 178 It was not only private rights to land which international law required to be respected; the public or sovereign rights of these peoples also had to be acknowledged. Consequently, the normal method of acquisition of Aboriginal sovereignty was by cession or conquest, rather than settlement. ${ }^{179}$

Again, Lindley's analysis of the works of international law jurists establishes that these writers accepted certain indigenous groups to be more than mere legal occupants. They were considered full sovereign states. While some jurists required these peoples to comply with a prescribed degree of "civility," 180 generally the only prerequisite was a degree of governmental authority sufficient enough to maintain order within the group. ${ }^{181}$ Such sovereignty could be exercised by a local community or communities, ${ }^{182}$ a native sovereign, ${ }^{183}$ by many rulers across the country, ${ }^{184}$ or small groups jointly exercising co-sovereignty. ${ }^{185}$ To this end, many Asian peoples, such as those of the Ottoman Empire, the Maratha Empire of India, ${ }^{186}$ Thailand $($ Siam $),{ }^{187}$ Japan, and Korea were recognized as sovereign entities ${ }^{188}$

177. Vitoria, supra note 22, at 24.

178. Id.

179. See CrAWFORD, supra note 21 , at 180 .

180. See WESTLAKE, supra note 157 , at $139-57$. Westlake required a "native government capable of controlling white men or under which white civilization can exist." Id. at 145 .

181. CRAWFORD, supra note 21 , at 176.

182. As in Australia, Canada, the United States and New Guinea.

183. As in New Zealand, Lagos and Zimbabwe.

184. As in India.

185. For example, the tribes, confederations and emirates of the Western Sahara.

186. See, e.g., Concerning Right of Passage Over Indian Territory (Port. v. India), 1960 I.C.J. 6, at 38 (Apr. 12).

187. See, e.g., Concerning the Temple of Preah Vihear (Cambodia. v. Thail.), 1962 I.C.J. 6 (Judgment of June 15, 1962).

188. While these nations were not treated identically to European States, the distinction was made not on the basis of "civility" but through the application of "regional customs." See CRAWFORD, supra note 21 , at 176. 
Similarly, the peoples of Africa ${ }^{189}$ and the Pacific ${ }^{190}$ were recognized as independent states.

In light of international law's recognition of Aboriginal sovereignty in these circumstances, it is submitted that there is no reason to deny the sovereignty of the Aboriginal peoples of Australia and North America. ${ }^{191}$ As the Court pointed out in Western Sahara, even nomadic peoples can exercise de facto sovereignty over the lands through which they roam. ${ }^{192}$ Similarly, nomadic ${ }^{193}$ bands of Aboriginal peoples in Australia, New Zealand, Canada and the United States could be considered to jointly exercise sovereign rights over these countries. ${ }^{194}$

\section{Aboriginal Treaties}

If these Aboriginal peoples legally held sovereign title to their traditional lands, as noted above, their territory could be validly acquired only after obtaining the consent of the people or their sovereign. Yet no treaties were concluded between the acquiring imperial or colonial powers and many of the subject dispossessed Aboriginal peoples. ${ }^{195}$ Even where treaties were concluded, in countries such as Canada ${ }^{196}$ and New

189. See, e.g., Convention between Great Britain and the Transvaal Burghers (Swaziland), Aug. 3, 1881, 72 B.F.S.P. 900, reprinted in 159 C.T.S. 57 (1977); Western Sahara, 1975 I.C.J. 12 (Oct. 16).

190. See, e.g., Treaty of Friendship between Great Britain and Tonga, Nov. 29, 1879 , 70 B.F.P.S. 9, reprinted in 155 C.T.S. 439 (1977). The Treaty of Friendship was based on the Treaty of Cession between Great Britain and New Zealand (Waitangi), Feb. 5-6, 1840, 29 B.F.P.S. 1111 , reprinted in 89 C.T.S. 473 (1969).

191. See e.g., Slattery, supra note 25 , at 700 .

192. See Western Sahara, 1975 I.C.J. 12, 122 (Oct. 16).

193. In Australia, there has been a misapprehension that all Aboriginal peoples were nomadic. This belief is not accurate. Many Aboriginal communities undertook a sedentary existence. See generally Cassidy, The Conquered Continent, supra note 120, ch. 4 .

194. The sovereign rights should be viewed as exercised in conjunction with other nomadic and more settled groups.

195. See sources cited supra notes 26, 64. See also SENATE COMM. ON INDIAN AFFAIRS, 2 LAws AND Treaties 23 (Charles J. Kappler ed., 1904); J. E. Foster, Indian-White Relations in the Prairie West During the Fur Trade Period - A Compact?, in THE SPIRIT OF Alberta Indian Treaties 181, 182-83 (Richard Price ed., Pica Pica Press 1987); Richard T. PRICE, LEGACY: INDIAN TREATY RELATIONSHIPS 20 (1991). This Includes the indigenous occupants of Australia, the South Island of New Zealand and certain parts of Canada and the United Staes. With regard to Australia, see discussion supra note 26.

196. See Asch, supra note 26, at 473-74 (discussing the impact of Canadian treaties). Asch also argues that the Constitution Act, $\S 91,1867$ (Can.), should be interpreted as a recognition of the Indian peoples' right to negotiate treaties with the Federal government. See id. For an explanation of the constitutionalization of Aboriginal treaty rights in Canada, see Constituiton Act, $\S \S 25,35(1), 1982$ (Can.). Horseman v. The Queen [1990] 1 S.C.R. 901; The Queen v. Sparrow [1990] 70 D.L.R. 4th 385, 401, 404; The Queen v. Sioui [1990] 70 D.L.R. 4th 427. 
Zealand, ${ }^{197}$ it has only been in recent years that these have been recognized as legally binding. Perhaps more importantly, the international status of such treaties has been denied. ${ }^{198}$ Rather, they have been perceived as domestic "agreements between Crown and native subjects" in the case of Canadian agreements and "Crown and non-subjects" in the case of the Treaty of Waitangi. ${ }^{199}$ Thus, no question of cession is said to arise out of such treaties. $^{200}$

Given international law's recognition of the sovereign status of

197. See Treaty of Waitangi Act 1975, No. 114 of 1975 (N.Z.) (confirming the binding force of the Treaty and adopting measures for its implementation). See also New Zealand Maori Council v. Attorney-Gen. [1987] 1 N.Z.L.R. 641, 659 (N.Z.C.A.).

198. The international status of treaties between the government and the Indian Nations of the United States have been more readily recognized by the early courts of that jurisdiction. Thus, in Worcester v. Georgia, Chief Justice Marshall asserted:

The words 'treaty' and 'nation' are words of our own language, selected in our diplomatic and legislative proceedings, by ourselves, having each a definite and understood meaning. We have applied them to Indians as we have applied them to other nations of the earth. They are applied all in the same sense.

31 U.S. (6 Pet.) 515, 559-60 (1832). See also id. at 544-45 (Marshall, J.,); Cherokee Nation v. Georgia, 30 U.S. (5 Pet.) 1, 16, 17, 20, 53 (1831); Johnson v. M'Intosh, 21 U.S. (8 Wheat.) 543, 574 (1823); Fletcher v. Peck, 10 U.S. (6 Cranch) 87 (1810); Island of Palmas, 2 R.I.A.A. 829, 856 (Perm. Ct. Arb. 1928); Asch, supra note 26, at 481 (noting that Canadian self-government agreements have been denied constitutional status); Nettheim, supra note 2, at 5; Bryant, supra note 9, at 287; Richard Falk, The Rights of Peoples (In Particular Indigenous People) in THE Rughts of PEOPLES 18-19 (J. Crawford ed., 1988); P. G. McHugh, Maori Fishing Rights and the North American Indian, 6 OTAGO L. REV. 62, 81(1985); Andrée Lawrey, Contemporary Efforts to Guarantee Indigenous Rights Under International Law, 23 VAND. J. TRANSNAT'L L. 703, 728 (1990). See generally Berg, supra note 149; L.C. Green, Aboriginal Peoples, International Law and Canadian Charter of Rights and Freedoms, 61 CAN. B. REv. 339 (1983).

199. McHugh, supra note 198, at 81. See generally Simon v. The Queen [1986] 24 D.L.R. 4th 390 (Can.); Guerin v. The Queen [1984] 13 D.L.R. 4th 321 (Can.); Pawis v. The Queen [1980] 102 D.L.R. 3d 602 (Can.); St. Catherine's Milling and Lumber Co. v. The Queen [1889] 14 App. Cas. 46 (P.C. 1888) (appeal taken from Can.). Note, however, the comment in The Queen v. Sioui [1990] 70 D.L.R 4th 427, 448 (Can.):

mother countries did everything in their power to secure the alliance of each Indian nation and to encourage nations allied with the enemy to change sides. When these efforts met with success, they were incorporated in treaties of alliance or neutrality. This clearly indicates that the Indian nations were regarded in their relations with the European nations which occupied North America as independent nations.

Id. Earlier in the judgment, however, the Court stated that "relations with Indian tribes fell somewhere between the kind of relations conducted between sovereign states and the relations such States had with their own citizens" Id. at 437. Thus the Court appears to suggest that the status of Indian peoples is sui generis. Strangely, the Australian Senate's Standing Committee on Constitutional and Legal Affairs believed any "Makaratta" between the Aboriginal people and the Australian government could not, and seemingly should not, be an international treaty. See STANDING COMMITTEE, supra note 26.

200. See The Queen v. Secretary of State [1981] 4 C.N.L.R. 86, 101 (Eng. C.A.). 
Aboriginal peoples, the denial of the international nature of such agreements by scholars and the Canadian courts appears strange. ${ }^{201}$ Logic would dictate that they be treated as international treaties. Yet, even if this was the case, the significance of any such agreements to the cession of Aboriginal sovereignty would depend upon the status of the Aboriginal signatory and the purpose and effect of the treaty. If the treaty was not concluded between the legitimate representative of the relevant Aboriginal Nation, the agreement would be no more than a private contract and could not, therefore, effectively cede sovereign rights. If, however, the Aboriginal Nation's sovereign status was legally recognized and the agreement concluded with the appropriate sovereign representative, the agreement could be regarded as an international treaty ${ }^{202}$ evidencing the transfer of sovereign title to the subject lands.

If, however, the treaty did not cede sovereignty, but rather preserved or qualified the exercise of Aboriginal sovereignty, the "occupying" government could not rely upon it as a source of derivative title. In this context, it is important to note that the purpose of most treaties between the Crown and North American Aboriginal peoples was to preserve Aboriginal self-government ${ }^{203}$ rather than cede sovereignty. The treaties were protective in nature, incorporating binding and effective clauses preserving Aboriginal rights in perpetuity, rather than relinquishing such rights. ${ }^{204}$ In this context,

201. See Bryant, supra note 9, at n.103.

202. See Concerning Right of Passage Over Indian Territory (Port. v. India), 1960 I.C.J. 6, 91-92 (Apr. 12) (dissenting opinion of Judge Moreno Quintana).

203. See Bryant, supra note 9, at 288; See also Michael D. Mason, Canadian and United States Approaches to Indian Sovereignty, 21 OsGoode HALL L.J. 422, 426 (1983).

204. See 1 EMmerich DE VATTEL, Le DROIT Des GeNS ou PRINCIPES DE LA LOI NATURELlE APPLIQUES A LA CONDUITE ET AUX AFFAIRES DES NATIONS ET DES SOUVERAINS, at ch. xvi, 193 (M.P. Praider-Fodere ed., 1863); 2 Christian WolfF, Jus Gentium Meghodo Scientifica Pertractatum, ch. 1, 84 (Joseph H. Drake trans., Carnegie ed. 1934) (1764). While Wolff has suggested that the new sovereign might obtain a prescriptive title, the conqueror still might be bound by a fiduciary duty to guard the interests of the indigenous occupants. Canadian and U.S. courts have also recognized that the Crown has a fiduciary duty to safeguard the interests of Aboriginal occupants. See, e.g., Morton v. Ruiz, 415 U.S. 199 (1974); Seminole Nation v. United States, 316 U.S. 286 (1942); United States v. Waller, 243 U.S. 452 (1917); Jones v. Meehan, 175 U.S. 1 (1899); Worcester v. Georgia, 31 U.S. (6 Pet.) 515 (1832); Cherokee Nation v. Georgia, 30 U.S. (5 Pet.) 1 (1831); Inter Tribal Council, Inc. v. Babbitt, 51 F.3d 199 (9th Cir. 1995); Assiniboine \& Sioux Tribes of Fort Peck Indian Reservation v. Bd. of Oil \& Gas Conservation of Mont., 792 F.2d 782 (9th Cir. 1986); Gila River Pima Maricopa Indian Community v. United States, 9 Ct. Cl. 660 (1986); Navajo Tribe of Indians v. United States, 9 Ct. Cl. 227 (1985); United States v. University of New Mexico, 731 F.2d 703 (10th Cir. 1984); Pechanga Band of Mission Indians v. Kacor Realty Inc., 680 F.2d 71 (4th Cir. 1982); Am. Indian Residing on Maricopa-AK Chin Reservation v. United States, 667 F.2d 980 (Ct. Cl. 1981); Passamaquoddy Tribe v. Morton, 528 F.2d 370 (1st Cir. 1975); Kerr-McGee Corp. v. Farley, 915 F. Supp. 273 (D.N.M. 1995); Connecticut ex rel Blumenthal v. Babbitt, 899 F. Supp. 80 (D. Conn. 1995); Mille Lacs Band of Chippewa Indians v. Minnesota, 861 F. Supp. 784 (D. Minn. 1994); Havasupai Tribe v. United States, 752 F. Supp. 1471 (D. Ariz. 1990); Little Earth of United 
it is important to note that there has been considerable dispute as to the terms and interpretation of such treaties, particularly where the treaties are written in two languages. While the English version may suggest a cession of Aboriginal sovereignty, this may not be so in the Aboriginal version. In the subject countries such ambiguity is generally resolved in favor of the Aboriginal version, and thus, treaties are to be interpreted in accordance with the Aboriginal understanding of their terms. ${ }^{205}$ Treaties are also

Tribes, Inc. v. United States Dep't of Hous. and Urban Dev., 675 F. Supp. 497 (D. Minn. 1987); United States v. Abeyta, 632 F. Supp. 1301 (D.N.M. 1986); Ute Indian Tribe v. Utah, 521 F. Supp. 1072 (D. Utah 1981); Kenai Oil and Gas, Inc. v. Dep't of Interior, 522 F. Supp. 521 (D. Utah 1981).

In Canada, see, e.g. , Chippewas of Kettle \& Stony Point v. AG (Canada) [1997] 141 D.L.R. 4th 1, 10, 12; Corbiere v. Canada [1997] 142 D.L.R. 4th 122, 154; Blueberry River Indian Band v. Canada [1996] 130 D.L.R. 4th 193; Canadian Pacific Ltd. v. Matsqui Indian Band [1996] 134 D.L.R. 555, 579; Semiahmoo Indian Band v. Canada [1996] 128 D.L.R. 4th 542; The Queen v. Van der Peet [1996] 137 D.L.R. 4th 289, 301-02, 304, 338, 340, 368-69, 380, 395-97; The Queen v. Badger [1996] 133 D.L.R. 4th 324, 331, 354-55; The Queen v. Cote [1996] 138 D.L.R. 4th 385, 417; The Queen v. Adams [1996] 138 D.L.R. 4th 657, 677; The Queen v. Wolfe [1996] 129 D.L.R. 4th 58, 79-80; Delgamuukw v. British Columbia [1993] 104 D.L.R. 4th 289; The Queen v. Sparrow [1990] 70 D.L.R. 4th at 406, 408; The Queen v. Taylor [1981] 62 C.C.C. 2d 227; The Queen v. Syliboy [1929] 1 D.L.R. 307, 314. Note that Chief Justice Brennan rejected the existence of this fiduciary duty in Wik Peoples v. Queensland [1996] 141 A.L.R. 129, 161. It is submitted that he wrongly suggested the above cases were based on a protective statutory scheme, rather than a common law or international law principle.

205. In the United States there is a wealth of cases supporting this position. See, e.g., Oklahoma Tax Comm'n v. Chickasaw Nation, 515 U.S. 450 (1995); Washington v. Washington State Commercial Passenger Fishing Vessel Assoc., 443 U.S. 658 (1979); Oliphant v. Suquamish Indian Tribe, 435 U.S. 191 (1978); De Coteau v. District County Court for Tenth Judicial District, 420 U.S. 425 (1975); Antoine v. Washington, 420 U.S. 194 (1975); McClanahan v. Arizona State Tax Comm'n., 411 U.S. 164 (1973); Peoria Tribe of Indians of Okla. v. United States, 390 U.S. 468 (1968); Northwestern Bands of Shoshone Indians, v. United States, 324 U.S. 335 (1945); Tulee v. Washington, 315 U.S. 681 (1942); United States v. Shoshone Tribe of Indians, 304 U.S. 111 (1938); Seufert Bros. Co. v. United States, 249 U.S. 194 (1919); Alaska Pacific Fisheries Co. v. United States, 248 U.S. 78, 89 (1918); Northern Pacific Railway Co. v. United States, 227 U.S. 355 (1913); Starr v. Long Jim, 227 U.S. 613 (1913); Winters v. United States, 207 U.S. 564 (1908); United States v. Winans, 198 U.S. 371 (1905); Minnesota v. Hitchcock, 185 U.S. 373 (1902); Jones v. Meehan, 175 U.S. 1, 10-11 (1899); Choctaw Nation v. United States, 119 U.S. 1 (1886); Worcester v. Georgia, 31 U.S. (6 Pet.) 515 (1832); Cherokee Nation v. Georgia, 30 U.S. (5 Pet.) 1 (1831); Alaska v. Native Village of Venetie Tribal Gov't, 101 F.3d 1286, 1294 (9th Cir. 1996); Confederated Tribes of Chehalis Indian Reservation v. Washington, 96 F.3d 334 (9th Cir. 1996); Cree v. Waterbury, 78 F.3d 1400 (9th Cir. 1996); Tonkawa Tribe of Okla. v. Richards, 75 F.3d 1039 (5th Cir. 1996); Rumsey Indian Rancheria of Wintun Indians v. Wilson, 64 F.3d 1250, 1257 (9th Cir. 1994); Lazore v. Comm'r, 11 F.3d 1180 (3d Cir. 1993); United States v. Washington, 969 F.2d 752 (9h Cir. 1992); Oneida Indian Nation v. New York, 860 F.2d 1145 (2d. Cir. 1988); United States v. Washington, 774 F.2d 1470 (9th Cir. 1985); Swim v. Bergland, 696 F.2d 712 (9th Cir. 1983); Donovan v. Navajo Forest Product Indus., 692 F.2d 709 (10th Cir. 1982); Menominee Indian Tribe v. Thompson, 922 F. Supp. 184 (W.D. Wis. 1996); Meyers v. Bd. of Educ. of San Juan Sch. Dist., 905 F. Supp. 1544 (D. Utah 1995); Mille Lacs Band of Chippewa Indians v. Minnesota 853 F. Supp. 
interpreted in light of the government's trust obligations owed to Aboriginal peoples. ${ }^{206}$

Crawford suggests, however, that despite the conditional and protective nature of these agreements, they have been regarded as effecting an absolute cession of sovereignty. ${ }^{207}$ In essence, he asserts that their protective nature may be undermined by subsequent practice. ${ }^{208}$ Crawford also suggests that these Aboriginal peoples are soon considered part of the new state. ${ }^{209}$ Thus, Aboriginal peoples would encounter many difficulties in enforcing their "treaty" rights in either the municipal or international courts. ${ }^{210}$

While it is appreciated that, in accordance with Crawford's sentiments,

1118 (D. Minn. 1994); Mille Lacs Band of Chippewa Indians v. Minnesota, 861 F. Supp. 784 (D. Minn. 1994); United States v. Washington, 873 F. Supp. 1422 (W.D. Wash. 1994); Nez Perce Tribe v. Idaho Power Co., 847 F. Supp. 791 (D. Idaho 1994); Sokaogon Chippewa Community v. Exxon Corp., 805 F. Supp. 680 (E.D. Wis. 1992); Lac Courte Oreilles Band of Lake Superior Chippewa Indians v. Wisconsin, 653 F. Supp. 1420 (W.D. Wis. 1987); United States v. Billie, 667 F. Supp. 1485 (S.D. Fl. 1987); Yankton Sioux Tribe of Indians v. Nelson, 604 F. Supp. 1146 (S.D.S.D. 1985); Bear v. United States, 611 F. Supp. 589 (D. . Neb. 1985); Babbitt Ford Inc. v. Navajo Indian Tribe, 519 F. Supp. 418 (D. Ariz. 1981).

In Canada, it has been suggested that the dispute continues to rage. See Foster, supra note 195, at 190; PRICE, supra note 195, at 20; Asch, supra note 26, at $486-87$. However, case law provides that any ambiguity must be resolved in favor of the Aboriginal interpretation. See The Queen v. Marshall [1997] 146 D.L.R. 4th 257; The Queen v. Gladstone [1996] 137 D.L.R. 4th 648, 703; The Queen v. Wolfe [1996] 129 D.L.R. 4th 58, 75; The Queen v. Badger [1996] 133 D.L.R. $4^{\text {th }} 324,331,340,344$; The Queen v. Van der Peet [1996] 137 D.L.R. 4th 289, 340, 368-69; The Queen v. Horseman [1990] 1 S.C.R. 901, 907; The Queen v. Sparrow [1990] 70 D.L.R. 4th 385, 407; The Queen v. Sioui [1990] 70 D.L.R. 4th 427; Simon v. The Queen [1986] 24 D.L.R. 4th 390, 402; Nowegijick v. The Queen [1983] 144 D.L.R. 3d 193, 198-99; The Queen v. George [1966] 55 D.L.R. 2d 386; In re Paulette [1963] 6 W.W.R. 97.

For the New Zealand position, see New Zealand Maori Council v. Attorney-General [1987] 1 N.Z.L.R. 659.

206. See Alaska v. Native Village of Venetie Tribal Gov't, 101 F.3d 1286,1294 (9th $\mathrm{Cir}$. 1996); Jones v. Meehan, 175 U.S. 1, 10-11 (1899); Cherokee Nation v. Georgia, 30 U.S. (5 Pet.) 1 (1831); The Queen v. Badger [1996] 133 D.L.R. 4th 324, 340-41, 360; The Queen v. Van der Peet [1996] 137 D.L.R. $4^{\text {th }} 289,301-02,340$; The Queen v. Wolfe [1996] 129 D.L.R. 4th 58, 75-76; Ontario v. Bear Island Foundation [1991] 83 D.L.R. 4th 381; The Queen v. Sparrow [1990] 70 D.L.R. 4th 385, 410; Simon v. The Queen [1986] 24 D.L.R. 4th 390, 405-06.

207. See CRAWFORD, supra note 21 , at 182 .

208. See id.

209. Crawford suggests that, at most, the community would continue to be recognized as a separate entity in the form of a "domestic dependent Nation." Id. (quoting Chief Justice Marshall's opinion in Worcester v. Georgia, 31 U.S. at 17-18).

210. See CRAWFORD, supra note 21, at 183. See also Milirrpum v. Nabalco Party Ltd. \& the Commonwealth [1971] 17 F.L.R. 141, 183-98; Warman v. Francis [1958] 20 D.L.R. $2 \mathrm{~d} 627$. Difficulties would occur even if the treaty is concluded after the initial cession. See Cayuga Indians Claim (Gr. Brit. v. U.S.) 6 R.I.A.A. 173 (U.S.-Brit. Arb. Trib. 1926); In re Southern Rhodesia [1919] A.C. 211, 231-34; OI Le Ngojo v. AG (1913) 5 KENYA L.R. 70. 
Aboriginal peoples face certain hurdles in enforcing their rights in these forums, these hurdles are not insurmountable. ${ }^{211}$ Moreover, Crawford's view is not shared by all. The United Nations Working Group on Indigenous Populations maintains that these treaties between states and Aboriginal peoples recognize and effectively preserve Aboriginal rights of selfgovernment and self-determination. ${ }^{212}$ Perhaps most importantly, even if these treaties do not in themselves effectively preserve Aboriginal sovereignty, in the absence of a formal cession, again, they would not provide a source of a derivative sovereign title.

In light of the above brief consideration of the sovereign status of dispossessed indigenous peoples, there appears to be three possible descriptions of the position of the Aboriginal peoples of Australia, North America, and other nations. If a treaty was concluded, the Aboriginal people could have been totally absorbed into the new sovereign's community or may have retained a distinct status as domestic dependent nations, exercising sovereignty jointly with the new sovereign state. Where no treaty of cession was concluded, as in the case of Australia, for example, the sovereign rights of the Aboriginal occupants could only have been assumed illegally. Therefore, that title could not have been acquired by prescription. After examining the notion of domestic dependent nations, the ability of the latter category of peoples to resurrect their sovereignty is considered.

\section{Domestic Dependent Nations: Concurrent Sovereignty}

\section{Introduction}

The resolution of disputes relating to Aboriginal sovereignty is often mistakenly perceived as only involving two possibilities: (1) acknowledgment of Aboriginal sovereignty and the consequent destruction of the "occupying" state's sovereignty; or (2) continuation of the past denial of Aboriginal sovereignty. However, it is possible for both entities to enjoy concurrent sovereignty.

\section{United States}

The Indian tribes of the United States have long been recognized as 
domestic dependent nations, exercising inherent sovereign rights over Indian Country. ${ }^{213}$ These rights were held concurrently with the United States government's claim to sovereignty. ${ }^{214}$ The sovereignty of Indian Nations became entrenched in the United States case law $^{215}$ as a result of a series of

213. In essence, "Indian Country" constitutes (i) reservations, (ii) allotments, (iii) dependent Indian communities and (iv) lands to which the Aboriginal title has not been extinguished. The concept of Indian Country was originally developed in United States $v$. Sandoval, 231 U.S. 28 (1913). In this case, the Court held that the lands owned by the Pueblo Nation were Indian Country for the purposes of enforcing federal Indian liquor laws. The Court also held that the lands were Indian Country even though they were owned in fee simple from grants from the King of Spain because they were treated by the United States as a "dependent Indian community." Id. at 46. Cf. Oklahoma Tax Comm'n v. Chickasaw Nation, 515 U.S. 540 (1995); California v. Cabazon Band of Mission Indians, 480 U.S. 202 (1987); DeCoteau v. District County Court, 420 U.S. 425 (1975); United States v. Chavez, 290 U.S. 357 (1933); Donnelly v. United States, 228 U.S. 243 (1913); Clairmont v. United States, 225 U.S. 551 (1912); Bates v. Clark, 95 U.S. 204 (1877); Alaska v. Native Village of Venetie Tribal Gov't, 101 F.3d 1286 (9th Cir. 1996), rev'd, 118 S. Ct. 948 (1998); Mustang Prod. Co. v. Harrison, 94 F.3d 1382 (10th Cir. 1996); Pittsburg \& Midway Coal Mining Co. v. Watchman, 52 F.3d 1531 (10th Cir. 1995); Cardinal v. United States, 954 F.2d 359 (6th Cir. 1992); United States v. Sands, 968 F.2d 1058 (10th Cir. 1992); Citizen Band Potawatomi Indian Tribe v. Oklahoma Tax Comm'n, 888 F.2d 1303 (10th Cir. 1989); Indian Country, U.S.A., Inc. v. Oklahoma, 829 F.2d 967 (10th Cir. 1987); United States v. Martine, 442 F.2d 1022 (10th Cir. 1971); Ute Indian Tribe v. Utah, 935 F. Supp. 1473 (D. Utah 1996); Narragansett Indian Tribe v. Narragansett Elec. Co., 878 F. Supp 349 (D.R.I. 1995); In re McCord, 151 F. Supp. 132 (D. Alaska 1957). Note that the other significant requirement in the exercise of Indian sovereignty is that the community be a "tribe." A community may be a tribe on the basis that it is a tribe ethnologically, such as "a body of Indians of the same or a similar race, united in a community under one leadership or government, and inhabiting a particular though sometimes ill-defined territory," Montoya v. United States, 180 U.S. 261, 266 (1901). See also Joint Tribal Council of Passamaquoddy Tribe v. Morton, 528 F.2d 370 (1st Cir. 1975). A community also includes a federally recognized tribe. See, e.g., United States v. Sandoval, 231 U.S. 28 (1913); United States v. Holliday, 70 U.S. 407 (1866); Atkinson v. Haldane, 569 P.2d 151 (Alaska 1977).

214. See Robert G. McCoy, The Doctrine of Tribal Sovereignty: Accommodating Tribal, State, and Federal Interests, 13 HARV. C.R.-C.L. L. REV. 357, 359 (1978); DAVID S. CASE, ALASKA NATIVES AND AMERICAN LAWS, 435-76 (1984). As Case notes, it should be kept in mind that the federal government's policy with respect to Aboriginal sovereignty has been far from consistent. See id. at 440. In particular, Aboriginal sovereignty was greatly undermined by the assimilist policy of the 1950s. See generally Carole E. Goldberg, Public Law 280: The Limits of State Jurisdiction Over Reservation Indians, 22 UCLA L. REV. 535 (1975). Note, that in addition to their inherent sovereign rights, Indian Nations can also exercise federally delegated authority over matters that would not be encompassed in inherent Indian sovereignty. See United States v. Mazurie, 419 U.S. 544 (1975).

215. In modern times the recognition of Aboriginal sovereignty has been supported by legislative attempts to promote Aboriginal self-determination. See, e.g., Alaska Native Claims Settlement Act 1971, 43 U.S.C. $\$ \S 1601-1628$ (1994); Indian Self-Determination and Education Assistance Act 1974, 25 U.S.C. \$\$ 450-450n, 455-458e (1994); Indian SelfDetermination Act 1975, 25 U.S.C.A. $\S 450$ (West Supp. 1998). See also, Alaska v. Native Village of Venetie Tribal Gov't, 101 F.3d 1286 (1996), rev'd, 118 S. Ct. 948 (1998); New 
cases which have come to be known as the "Marshall trilogy." 216 According to the "Marshall trilogy," these Indian Nations had to be left in the undisturbed possession of their lands, the right to which was only diminished to a limited extent by the new sovereign's right of pre-emption. ${ }^{217}$ These cases recognized Indian tribes as separate nations, entitled to govern themselves and enforce their own customary laws. ${ }^{218}$ This sovereignty

Mexico v. Mescalero Apache Tribe, 462 U.S. 324 (1983).

216. Worcester v. Georgia, 31 U.S. (6 Pet.) 515, 544-45, 559 (1832), overruled by New Mexico v. Mescalero Apache Tribe, 462 U.S. 342 (1983); Cherokee Nation v. Georgia, 30 U.S. (5 Pet.) 1, 16, 17, 20, 53 (1831); Johnson v. M'Intosh, 21 U.S. (8 Wheat.) 543, 574 (1823). It is important to note that the trilogy does not reveal the entire historical context. Indian sovereign and territorial rights were first considered by the U. S. Supreme Court in Fletcher v. Peck, 10 U.S. (6 Cranch) 87 (1810). This case concerned the notorious Yazoo land scandal in Georgia. In 1795, the Georgian legislature authorized the grant and sale of vast areas of the State in the possession of the traditional Indian owners. Allegations of fraud and bribery led a subsequent Congress to revoke these grants. However, in the meantime, innocent colonists had purchased these lands in good faith. The Supreme Court was faced with the task of determining what rights, if any, these purchasers had obtained. While Chief Justice Marshall held the grants to be constitutional, Justice Johnson went further in asserting Georgia was not seised in fee. See id. at 95-97. Justice Johnson in his dissent stated that many Indian Nations "retain a limited sovereignty, and the absolute proprietorship of their soil." Id. at 102. Georgia had no more than "a right of conquest or of purchase, exclusively of all competitors, within certain defined limits." Id. at 103. The State's right of pre-emption only gave it the "power to acquire a fee-simple by purchase, when the proprietors should be pleased to sell." Id. at 104. This, he claimed, was no more than a mere possibility of seisin. See id. at 102. For the political background to this case, see C. P. MCGRATH, YAZOO: LAW AND Polmtics IN THE NEW RePUBlic, THE CASE OF FletCHER V. PECK (1966); LeONARD BAKER, JOHN MARSHALL: A LIFE IN THE LAW, 566-72 (1974).

217. The right of pre-emption is the sole right against other European nations to purchase the Indian lands if they wish to sell. Chief Justice Marshall described the right of pre-emption in Johnson v. M'Intosh.

This principle found that discovery gave title to the government by whose subjects, or by whose authority, it was made, against all other European governments, which title might be consummated by possession. The exclusion of all other Europeans, necessarily gave to the nation making the discovery the sole right of acquiring the soil from the natives, and establishing settlements upon it.

21 U.S. (8 Wheat.) at 573.

218. The conclusion of the trilogy did not bring an end of the courts' recognition of the Indian Nations' sovereignty. See, e.g., Oklahoma Tax Comm'n v. Citizen Band Potawatomi Indian Tribe, 498 U.S. 505 (1991); lowa Mut. Ins. Co. v. La Plante, 480 U.S. 9 (1987); New Mexico v. Mescalero Apache Tribe, 462 U.S. 324 (1983); White Mountain Apache Tribe v. Bracker, 448 U.S. 136 (1980); Washington v. Confederated Bands \& Tribes of Yakima Indian Nation, 439 U.S. 463 (1979); Santa Clara Pueblo v. Martinez, 436 U.S. 49 (1978); United States v. Wheeler, 435 U.S. 313 (1978); Oliphant v. Suquamish Indian Tribe, 435 U.S. 191 (1978); United States v. Antelope, 430 U.S. 641 (1977); United States v. Mazurie, 419 U.S. 544 (1975); McClanahan v. Arizona State Tax Comm'n, 411 U.S. 164 (1973); Williams v. Lee, 358 U.S. 217 (1959); Turner v. United States, 248 U.S. 354 (1919); United States v. 
allows Indian Nations to regulate affairs within the scope of their territory, exercising authority over matters such as community membership, domestic relations between members, fish and game resources, taxation, ${ }^{219}$ and

Quiver, 241 U.S. 602 (1916); Jones v. Meehan, 175 U.S. 1 (1899); Stephens v. Cherokee Nation, 174 U.S. 445 (1899); Roff v. Burney, 168 U.S. 218 (1897); United States v. Kagama, 118 U.S. 375 (1886); Elk v. Wilkins, 112 U.S. 94 (1884); Mitchel v. United States, 34 U.S. (9 Pet.) 711 (1835); Reich v. Mashantucket Sand \& Grave, 95 F.3d 174 (2nd Cir. 1996); Mustang Prod. Co. v. Harrison, 94 F.3d 1382 (10th Cir. 1996); Poodry v. Tonawanda Band of Seneca Indians, 85 F.3d 874 (2nd Cir. 1996); Narragansett Indian Tribe v. Narragansett Elec. Co., 89 F.3d 908 (1st Cir. 1996); United States v. Tsosie, 92 F.3d 1037 (10th Cir. 1996); United States v. Begay, 42 F.3d 486 (9th Cir. 1994); Reich v. Great Lakes Indian Fish \& Wildlife Comm'n, 4 F.3d 490 (7th Cir. 1993); United States v. Funmaker, 10 F.3d 1327 (7th Cir. 1993); Altheimer \& Gray v. Sioux Mfg. Corp., 983 F.2d 803 (7th Cir. 1993); EEOC v. Fond du Lac Heavy Equip. \& Constr. Co., 986 F.2d 246 (8th Cir. 1993); Black Hills Inst. of Geological Research v. United States Dep't of Justice, 967 F.2d 1237 (8th Cir. 1992); In re Greene, 980 F.2d 590 (9th Cir. 1992); Seneca-Cayuga Tribe v. Oklahoma, 874 F.2d 709 (10th Cir. 1989); Sanders v. Robinson, 864 F.2d 630 (9th Cir. 1988); Wheeler v. Swimmer, 835 F.2d 259 (10th Cir. 1987); Wellman v. Chevron U.S.A., Inc., 815 F.2d 577 (9th Cir. 1987); Queets Band of Indians v. Washington, 765 F.2d 1399 (9th Cir. 1985); Irving v. Clark, 758 F.2d 1260 (8th Cir. 1985); Chemehuevi Indian Tribe v. California State Bd. of Equalization, 757 F.2d 1047 (9th Cir. 1985); Kerr-McGee Corp v. Navajo Tribe of Indians, 731 F.2d 597 (9th Cir. 1984); R.J. Williams Co. v. Ft. Belknap Housing Auth., 719 F.2d 979 (9th Cir. 1983); Ashcroft v. United States Dep't of Interior, 679 F.2d 196 (9th Cir. 1982); Escondido Mutual Water Co. v. FERC, 692 F.2d 1223 (9th Cir. 1982); Donovan v. Navajo Forest Prod. Indus., 692 F.2d 709 (10th Cir. 1982); Ute Distribution Corp. v. Secretary for the Interior, 934 F. Supp. 1302 (D. Utah 1996); Romanella v. Hayward, 933 F. Supp. 163 (D. Conn. 1996); Montana v. Gilham, 932 F. Supp. 1215 (D. Mont. 1996); Pueblo of Santa Ana v. Kelly, 932 F.Supp. 1284 (D.N.M. 1996); Basil Cook Enter. Inc. v. St. Regis Mohawk Tribe, 914 F. Supp. 839 (N.D.N.Y. 1996); Lower Brule Sioux Tribe v. South Dakota, 917 F. Supp. 1434 (D.S.D. 1996); Bowen v. Doyle, 880 F. Supp 99 (W.D.N.Y. 1995); Narragansett Indian Tribe v. Narragansett Elec. Co., 878 F. Supp. 349 (D.R.I. 1995); Federico v. Capital Gaming Int'l., 888 F. Supp. 354 (D.R.I.1995); Kerr-McGee Corp v. Farley, 915 F. Supp. 273 (D.N.M. 1995); Coeur D'Alene Tribe v. State, 842 F. Supp. 1268 (D. Idaho 1994); Cameron v. Bay Mills Indian Community, 843 F. Supp. 334 (W.D. Mich. 1994); Rhode Island v. Narragansett Indian Tribe, 19 F.3d 685 (1st Cir. 1994); Veeder v. Omaha Tribe, 864 F. Supp. 889 (N.D. Iowa 1994); GNS Inc. v. Winnebago Tribe, 866 F. Supp. 1185 (N.D. Iowa 1994); Davids v. Coyhis, 869 F. Supp 1401 (E.D. Wis. 1994); In re United States, 825 F. Supp. 1422 (D. Minn. 1993); Cropmate Co. v. Indian Resources Int'l, 840 F. Supp. 744 (D. Mont. 1993); Babbitt Ford Inc. v. Navajo Indian Tribe, 519 F. Supp. 418 (D. Ariz. 1981); Navajo Tribe v. Bank of New Mexico, 556 F. Supp. 1 (D.N.M. 1980). 219. See, e.g., Merrion v. Jicarilla Apache Tribe, 455 U.S. 130 (1982); Washington v. Confederated Bands \& Tribes of Yakima Indian Nation, 439 U.S. 463 (1979); Burlington N.R.R. Co. v. Blackfeet Tribe of Blackfeet Indian Reservation, 924 F.2d 899 (9th Cir. 1991); Kerr-McGee Corp v. Navajo Tribe of Indians, 731 F.2d 597 (9th Cir. 1984); United States v. Anderson, 736 F.2d 1358 (9th Cir. 1984); Southland Royalty Co. v. Navajo Tribe of Indians, 715 F.2d 486 (10th Cir. 1983); Burlington N.R.R. v. Fort Peck Tribal Executive Bd., 701 F. Supp. 1493 (D. Mont. 1988); Conoco Inc. v. Shoshone \& Arapahoe Tribes, 569 F. Supp. 801 (D. Wyo. 1983). See also Indian Reorganization Act of 1934, 48 Stat. 984, (codified as amended at 25 U.S.C.A. \$\$ $461-477$ (1998)). The taxing sovereignty may not be used by Indian Nations to market an exemption from state taxation to persons who would 
enjoying sovereign immunity from suit.

In the first case of this trilogy, Johnson v. M'Intosh, ${ }^{220}$ Chief Justice Marshall declared that the Aboriginal occupants were:

the rightful occupants of the soil, with a legal as well as a just claim to retain possession of it, and to use it according to their own discretion; but their rights to complete sovereignty, as independent nations, were necessarily diminished, and their power to dispose of the soil at their own will, to whomsoever they pleased, was denied by the original fundamental principle, that discovery gave exclusive title to those who made it. ${ }^{221}$

Thus, until sovereign and territorial title to their lands were ceded, the Aboriginal occupants enjoyed the right to govern themselves according to their own customary laws. The only limitation upon Aboriginal sovereignty was the "occupying" state's right of pre-emption. ${ }^{222}$

Less than ten years later the second case in the trilogy, Cherokee Nation v. Georgia, ${ }^{223}$ was decided. While Chief Justice Marshall held that

otherwise conduct their business outside Indian Country. See Confederated Bands \& Tribes of Yakima Indian Nation, 439 U.S. at 479-500. In addition, Indian Nations exercise authority over crime concurrently with the States. See generally Goldberg, supra note 214 (discussing Public Law 280 and Major Crimes $A C t)$.

220. 21 U.S. (8 Wheat.) 543 (1823). The plaintiff brought an action of ejectment against the defendant, claiming title to sue as the successor of the original title bought from the Indian owners in 1773 and 1775 . The same land had, however, been later ceded to the United States. In turn, the United States patented a portion of these lands to the defendant in 1818. The Court consequently had to determine whether a grant from the holders of the Aboriginal title, without the consent of the conquering power, prevailed over a patent from the government authorities. As Chief Justice Marshall stated, the determining factor was "the power of the Indians to give, and of private individuals to receive, a title which can be sustained in the Courts of this country." Id. at 572. Chief Justice Marshall held the transfer between the Piankeshaw Indians and the land speculators was not recognizable. See id. at 604-05. While the Aboriginal owners' right to their land was unquestionable, only the discovering power, in this case, Great Britain and after the American revolution, the United States, had the right of pre-emption. According to the doctrine of discovery, only these governments, not individual colonists, had the right to purchase lands from the Indians. See id. at 584-85, 594.

221. Id. at 574.

222. See discussion supra note 216.

223. 30 U.S. (5 Pet.) 1 (1831). Motivated by the wish to seize the gold rich lands of the subject Indian peoples, the State legislated to extend the application of its laws to Cherokee lands within the State's boundaries. This was in violation of certain treaties existing between the Indian Nation and the United States. The issue before the Court was whether "the Cherokees constitute[d] a foreign state in the sense of the constitution" having standing to invoke the court's original jurisdiction. Id. at 31 . The Court held that the Indian Nation was not a foreign state giving the Court jurisdiction over the dispute. However, the dissenters held that the Cherokee community was a sovereign foreign state. See id. at 79-80. 
the Cherokee Nation did not constitute "a foreign state," 224 he asserted that the United States "plainly recognize[d] the Cherokee Nation as a state . . . from the settlement of our country."22s Rather than foreign states, they were "domestic dependent nations" standing in a relationship with the United States resembling that of "a ward to his guardian." 226 The Indian Nation exercised concurrent sovereignty with the "conquering" power, thereby maintaining control within its territorial units. ${ }^{227}$ Thus, the Cherokee Nation was "a distinct political society, separated from others, capable of managing its own affairs and governing itself." 228

Justice Thompson went further than the majority in his recognition of Indian sovereignty noting:

[P] rovided the inferior ally reserves to itself the sovereignty or the right to govern its own body, it ought to be considered an independent state. Consequently, a weak state, that, in order to provide for its safety, places itself under the protection of a more powerful one, without stripping itself the right of government and sovereignty, does not cease on this account to be placed among the sovereigns who acknowledge no other power. ${ }^{229}$

A year later the third decision in the trilogy was determined in Worcester v. Georgia. ${ }^{230}$ Again, the Court recognized that "America . . . was inhabited by a distinct people, divided into separate Nations, independent of each other and the rest of the world, having institutions of their own, and governing themselves by their own laws."231 In the course of his judgment, Chief Justice Marshall stressed that discovery did not give the Federal or State authorities power to legislate with respect to the Indian Nations or their territory. Echoing the sentiments of Cherokee Nation $v$.

224. Id. at 19. Therefore, the Cherokee Nation did not have standing to invoke the Court's original jurisdiction. Id. at 39.

225. Id. at 16.

226. Id. at 17.

227. See id. at 16-19.

228. Id. at 16.

229. Id. at 53 .

230. 31 U.S. (6 Pet.) 515 (1932). The plaintiff, a missionary, had been charged under a Georgian law for "residing within the limits of the Cherokee nation" without a licence. Id. at 542. He argued he could not be charged under the statute as it was invalid. The Court agreed: The State could not legitimately claim dominion over the Cherokee Nation's territory or persons within such territory. See id. at 560-62. The Cherokee Nation was a distinct selfgoverning community, within which the laws of Georgia had no force. See id. at 561 . The prosecution of the plaintiff under Georgian law was in direct conflict with the treaties guaranteeing the Cherokee Nation's territorial rights and self-government. See id. The earlier decision convicting Worcester was consequently reversed and annulled. See id. at 562.

231 . Id. at 542. 
Georgia ${ }^{232}$ Chief Justice Marshall declared that discovery only gave the United Kingdom and the United States the right to purchase "such lands as the natives were willing to sell"233 as against all other European governments. ${ }^{234}$ Thus, the Indian Nation's right of self-government remained unaffected by discovery. ${ }^{235}$ The Court thought the suggestion "that the feeble settlements made on the sea-coast" gave the authorities "legitimate power" to govern the Indians was absurd. ${ }^{236}$ Rather:

The Indian nations had always been considered as distinct, independent political communities, retaining their original natural rights, as the undisputed possessors of the soil, from time immemorial, with the single exception of that imposed by irresistible power, which excluded them from intercourse with any other European poentate than the first discoverer of the coast of the particular region claimed . . . . The words 'treaty' and 'nation' are words of our own language, selected in our diplomatic and legislative proceedings, by ourselves, having each a definite and understood meaning. We have applied them to Indians as we have applied them to other nations of the earth: They are applied all in the same sense. ${ }^{237}$

Thus, the Court found that history furnished no evidence of attempts by the Crown to interfere with the internal affairs of the Indian Nations. To the contrary, treaties between the Cherokee Nation and the United States "recognize[d] the pre-existing power of the [Cherokee] Nation to govern itself" 238 and "their right to self-government."239 Chief Justice Marshall believed that as domestic dependent nations, the Indians had placed

232. 30 U.S. (5 Pet.) 1 (1831).

233. Worcester, 31 U.S. (6 Pet.) at 545. As Chief Justice Marshall pointed out " $[\mathrm{t}] \mathrm{he}$ United States succeeded to all the claims of Great Britain, both territorial and political," but no more. Id. at 544. See also id. at 560.

234. See id. at 544 . The principle of discovery giving right to title shut out the right of competition among those who had agreed to it . . . . IIt could not] annul the previous rights of those who had not agreed to it. It regulated the right given by discovery among the [E]uropean discoverers, but could not affect the rights of those already in possession, either as Aboriginal occupants, or as occupants by virtue of a discovery made before the memory of man.

Id. See also id. at 579 (stating Justice McLean's concurring comments).

235. Id. at $542-45$.

236. Id. at 544 .

237. Id. at 559-60.

238. Id. at 562 .

239. Id. at 556 . 
themselves under "the protection of one more powerful." 240 However, this did not take away the Indian Nations' "right of government, and [thereby] ceasing to be a state." 241 To this end, Chief Justice Marshall stressed that the notion of "domestic dependent nations" was not synonymous with the surrender of the Indian Nations' sovereign character:

[It is a] settled doctrine of the law of nations . . . that a weaker power does not surrender its independence, its right to selfgovernment, by associating with a stranger, and taking its protection . . . . 'Tributary and feudatory states,' says Vattel, 'do not thereby cease to be sovereign and independent. ${ }^{242}$

To imply such a surrender of self-government to "disorderly and licentious intruders" was illegitimate. ${ }^{243}$ Chief Justice Marshall asserted that to construe trade treaties as effecting such a surrender would be inconsistent with the spirit of this and of all subsequent treaties. Therefore, "it would convert a treaty of peace covertly into an act annihilating the political existence of one of the parties. Had such a result been intended, it would have been openly avowed."244

The Crown could not, therefore, legitimately claim dominion over this Indian Nation's territory or persons within such territory. The Court consequently held that the Cherokee Nation was a distinct self-governing community, within which the subject laws of Georgia had no force. ${ }^{245}$ Justice McLean agreed, stressing that in so far as this Georgian law purported to abolish the territorial and internal political rights of this Indian Nation, it was repugnant to the terms of treaties with the Cherokee Indians. ${ }^{246}$

As Foster notes, these cases have, however, been subsequently treated as recognizing that federal statutes and treaties guaranteeing Aboriginal sovereignty, rather than Aboriginal sovereignty itself, ousted the application of the subject Georgian laws. ${ }^{247}$ Thus, the cases are said to involve an implicit recognition that Congress had jurisdiction over Indians, as opposed

240. Id. at 555.

241. Id. at 561 .

242. Id. at 561 .

243. Id. at 554 .

244. Id. at 554.

245. Id. at 561-62.

246. Id. at 578-79. Georgia's subsequent defiance of the Court's mandate led to Congressional intervention; President, Andrew Jackson, pronounced that "John Marshall has given his judgement. Now let him enforce it." Felix S. Cohen, Original Indian Title, 32 MinN. L. REV. 28, 41 (1947) (quoting 1 HoraCe GredeY, AMERICAN CONFLICT 106 (1864)).

247. See Foster, supra note 195, at 181-85. 
to merely jurisdiction to enter treaties with them. ${ }^{248}$ This meant that if Congress could acknowledge and guarantee tribal sovereignty, it could also restrict or extinguish it; and it has done so on many occasions. ${ }^{249}$ As the United States is said to have ultimate sovereignty over the whole nation, including Indian Country, ${ }^{250}$ Indian law making powers may be limited by

248. Congress has jurisdiction over Indians, as opposed to the states, unless the tribe consents or Congress cedes its authority to the state. See, e.g., California v. Cabazon Band of Mission Indians, 480 U.S. 202 (1987); Three Affiliated Tribes of Fort Berthold Reservation v. Wold Eng'g, P.C., 476 U.S. 877 (1986); Montana v. Blackfeet Tribe of Indians, 471 U.S. 759 (1985); Rice v. Rehner, 463 U.S. 713 (1983); New Mexico v. Mescalero Apache Tribe, 462 U.S. 324 (1983); Ramah Navajo Sch. Bd. Inc., v. Bureau of Revenue, 458 U.S. 832 (1982); Washington v. Confederated Bands \& Tribes of Yakima Indian Nation, 439 U.S. 463 (1979); Bryan v. Itasca County, 426 U.S. 373 (1976); McClanahan v. Arizona State Tax Comm'n, 411 U.S. 164 (1973); Menominee Tribe of Indians v. United States, 391 U.S. 404 (1968); United States v. Kagama, 118 U.S. 375 (1886); Worcester v. Georgia, 31 U.S. (6 Pet.) 515 (1832); Gila River Indian Community v. Waddell, 91 F.3d 1232 (9th Cir. 1996); Fort Belknap Indian Community v. Mazurek, 43 F.3d 428 (9th Cir. 1994); United States v. Sands, 968 F.2d (10th Cir. 1992); Gila River Pima-Maricopa Indian Community v. Waddell, 967 F.2d 1404 (9th Cir. 1992); Gila River Pima-Maricopa Indian Community v. United States, 877 F.2d 961 (Fed. Cir. 1989); United States v. Harvey, 869 F.2d 1439 (1 lth Cir. 1989); Washington Dept. of Ecology v. United States EPA, 752 F.2d 1465 (9th Cir. 1985); Langley v. Ryder, 778 F.2d 1092 (5th Cir. 1985); United States v. Anderson, 736 F.2d 1358 (9th Cir. 1984); United States v. Daye, 696 F.2d 1305 (11th Cir. 1983); United States v. Chase, 701 F.2d 800 (9th Cir. 1983); Crow Tribe of Indians v. Montana, 650 F.2d 1104 (9th Cir. 1981); Seminole Tribe v. Butterworth, 658 F.2d 310 (5th Cir. 1981); Lower Brule Sioux Tribe v. South Dakota, 917 F. Supp. 1434 (D.S.D. 1996); Pueblo of Santa Ana v. Kelly, 932 F. Supp. 1284 (D.N.M. 1996); Bowen v. Doyle, 880 F. Supp. 99 (W.D.N.Y.1995); Tohono O'Odham Nation v. Schwartz, 837 F. Supp. 1024 (D. Ariz. 1993); Crow Tribe of Indians v. United States, 657 F. Supp. 573 (D. Mont. 1985); United States v. Dakota, 666 F. Supp. 989 (W.D. Mich. 1985); Oneida Tribe of Indians v. Wisconsin, 518 F. Supp. 712 (W.D. Wis. 1981).

Generally, state laws may operate concurrently with Indian laws within Indian Country, but only in so far as they do not interfere with reservation self-government, i.e., in matters which it is considered that the Indian Nation has an overriding cultural, economic or social interest. See, e.g., Rice v. Rehner, 463 U.S. 713 (1983); Montana v. United States, 450 U.S. 544 (1981); White Mountain Apache Tribe v. Bracker, 448 U.S. 136 (1980); McClanahan v. Arizona State Tax Comm'n, 411 U.S. 164 (1973); Kake v. Egan, 369 U.S. 60 (1962); Segundo v. City of Rancho Mirage, 813 F.2d 1387 (9th Cir. 1987); Crow Tribe of Indians v. Montana, 650 F.2d 1104 (9th Cir. 1981); Pueblo of Santa Ana v. Kelly, 932 F. Supp. 1284 (D.N.M. 1996); Narragansett Indian Tribe of Rhode Island v. Narragansett Electric Co., 878 F. Supp. 349 (D.R.I. 1995). Note that the suggestion that Public Law 280 empowered the states to regulate, as opposed to adjudicate, matters within Indian Country was rejected in Bryan v. Itasca County, 426 U.S. 373 (1976).

249. Note, however, that the legality of the imposition of such restrictions has not gone unquestioned. See Clinebell \& Thomson, supra note 2, at 683-700. Clinebell and Thomson correctly question the legality of these limitations upon Aboriginal sovereignty.

250. See Oliphant v. Suquamish Indian Tribe, 435 U.S. 191 (1978); Cherokee Nation v. Southern Kansas R.R. Co., 135 U.S. 641 (1890). 
the Constitution, federal legislation, ${ }^{251}$ or by implication as a result of their incorporation within the United States. ${ }^{252}$ While out of respect for Indian sovereignty, the courts will not lightly presume that Congress intended to oust tribal jurisdiction; ${ }^{253}$ ultimately the authority of the Indian Nations is not absolute. ${ }^{254}$

251. See, e.g., Montana v. Blackfeet Tribe of Indians, 471 U.S. 759 (1985); Merrion v. Jicarilla Apache Tribe, 455 U.S. 130 (1982); Washington v. Confederated Bands \& Tribes of Yakima Indian Nation, 439 U.S. 463 (1979); Santa Clara Pueblo v. Martinez, 436 U.S. 49 (1978); United States v. Wheeler, 435 U.S. 313 (1978); United States v. Sandoval, 231 U.S. 28 (1913); Ex parte Webb, 225 U.S. 663 (1912); Lone Wolf v. Hitchcock, 187 U.S. 553 (1903); Cherokee Nation v. Hitchcock, 187 U.S. 294 (1902); Stephens v. Cherokee Nation, 174 U.S. 445 (1899); Thomas v. Gay, 169 U.S. 264 (1898); Roff v. Burney, 168 U.S. 218 (1897); United States v. Kagama, 118 U.S. 375 (1886); Utah v. Babbitt, 53 F.3d 1145 (10th Cir. 1995); United States v. Funmaker, 10 F.3d 1327 (7th Cir. 1993); United States v. Eberhardt, 789 F.2d 1354 (9th Cir. 1986); Navajo Tribe v. Bank of New Mexico, 700 F.2d 1285 (10th Cir. 1983); Donovan v. Navajo Forest Prod. Indus., 692 F.2d 709 (10th Cir. 1982); Wilson v. Marchington, 934 F. Supp. 1176 (D. Mont. 1995); Red Lake Band of Chippewa Indians v. Swimmer, 740 F. Supp. 9 (D.D.C. 1990); United States v. Burns, 725 F. Supp. 116 (N.D.N.Y. 1989); Rice v. Rehner, 463 U.S. 713 (D. Conn. 1983); Mohegan Tribe v. Connecticut, 528 F. Supp. 1359 (D. Neb. 1982); Nebraska Public Power Dist. v. 100.95 Acres of Land, 540 F. Supp. 592 (D. Neb. 1982); Babbitt Ford, Inc. v. Navajo Indian Tribe, 519 F. Supp. 418 (D. Ariz. 1981).

252. See, e.g., Brendale v. Confederated Tribes \& Bands of Yakima Indian Nation, 492 U.S. 408 (1989); United States v. Wheeler, 435 U.S. 313 (1978); Rhode Island v. Narragansett Indian Tribe, 19 F.3d 685 (1st Cir. 1994); Inupiat Community of Artic Slope v. United States, 548 F. Supp, 182 (1982). In United States v. Wheeler, 435 U.S. 313 (1973), the Court held that areas that had been implicitly affected in this manner included the Indian Nations' ability to (i) alienate their lands to non-Indians, (ii) enter into relations with foreign Nations and (iii) litigate against non-members in tribal courts. Id. at 326 . In Inupiat Community of Artic Slope v. United States, 548 F. Supp. 182 (1982), aff'd, 746 F.2d 570, cert. denied, 474 U.S. 820, reh'g denied, 485 U.S. 972, the Court held that Indian authority was implicitly revoked also in areas that impacted the security of the United States and its relations with foreign nations.

253. See, e.g., Oklahama Tax Comm'n v. Sac \& Fox Nation, 508 U.S. 114 (1993); Merrion v. Jicarilla Apache Tribe, 455 U.S. 130 (1982); Washington v. Confederated Bands \& Tribes of Yakima Indian Nation, 439 U.S. 463 (1979); Santa Clara Pueblo v. Martinez, 436 U.S. 49 (1978); Rhode Island v. Narragansett Indian Tribe, 19 F.3d 685 (1st Cir. 1994); United States v. Eberhardt, 789 F.2d 1354 (9th Cir. 1986); Oglala Sioux Tribe v. South Dakota, 770 F.2d 730 (8th Cir. 1985); Babbitt Ford Inc. v. Navajo Indian Tribe, 519 F. Supp. 418 (D. Ariz. 1981). For a recent discussion of whether federal legislation, namely Alaska Native Claims Settlement Act, Pub. L. 92-203, 85 Stat. 688 (1971) (codified as amended at 43 U.S.C. $\$ \S 1601-1629 \mathrm{a}$ (1994)), extinguished Aboriginal sovereignty in Alaska, see Alaska v. Native Village of Venetie Tribal Gov't, 101 F.3d 1286 (1996), rev'd, 118 S. Ct. 948 (1998). The Court stressed that Aboriginal self-government could only be extinguished by clear and plain language. See id. at 1295.

254. See Delaware Tribal Business Committee v. Weeks, 430 U.S. 73, 84-86 (1977). Note that this would appear contrary to international law as there has been no legally effective cessation of Indian sovereignty. See Clinebell \& Thomson, supra note 2, at 683-700. 
Nevertheless, the "Marshall trilogy" continues to be cited"25s in support of the proposition that Aboriginal "sovereignty continues to the extent that it has not been specifically abolished by Congress. Although vulnerable, it is nonetheless inherent, and does not depend upon a grant from Congress or any other source." 256

\section{Canada}

The sovereignty of Indian Nations within Indian lands has similarly been recognized in Canada ${ }^{257}$ through legislative enactments, executive instruments and judicial determinations. ${ }^{258}$ Thus, in The Queen $v$. Van der $P e e t,{ }^{259}$ the Court agreed with Slattery that the Marshall Court decisions are as relevant to Canada as the United States. ${ }^{260}$ These cases were also adopted in The Queen v. Sioui ${ }^{261}$ where the Court asserted that relations between the colonial powers and the Indian Nations were "very close to those maintained

255. For example, Worcester $v$ Georgia, 31 U.S. ( 6 Pet.) 515 ( 1832) has been cited more often than "all pre-Civil War Supreme Court opinions save three." Charles F. Wilkinson, Indian Tribes and the American Constitution, in INDIANS IN AMERICAN HISTORY 117, 118 (Frederick E. Hoxie ed., 1988).

256. Id. at 358-59 (citing F. COHEN, HANDBOOK OF FEDERAL INDIAN LAW 122 (1942) and David H. GeTChes \& ChaRles F. Wilkinson, CASES and Materials ON Federal INDIAN LAW 269 (2d ed. 1986)). See generally Washington v. Confederated Tribes of Colville Indian Reservation, 447 U.S. 134 (1980).

257. See, e.g., Osoyoos Indian Band v. Oliver [1997] 145 D.L.R. 4th 552, 557-58; St. Mary's Indian Band v. Cranbrook [1996] 126 D.L.R. 4th 539; Canadian Pacific Ltd. v. Matsqui Indian Band [1996] 134 D.L.R. 4th 555.

258. With respect to legislative enactments, see, e.g., Indian Act, Act of June 28, 1985, ch. 27, 1985, S.C. 749 (Can.); Seschelt Indian Band Self-Government Act, Act of June 17, 1986, ch. 27, 1986, S.C. 941 (Can.); Indian Self-Government Enabling Act, 1990, ch. 52, S.B.C. (B.C.). See also Adams Lake Indian Band v. Dist. of Salmon Arm [1996] 137 D.L.R. 4th 89, 96; Canadian Pacific Ltd v. Matsqui Indian Band [1995] 122 D.L.R. 4th 129, 140, 169. The Indian Act of 1985 was introduced to facilitate self-government through the exercise of the "inherently governmental power of taxation on their reserves." Adams Lake Indian Band, 137 D.L.R. 4th at 96 . For a discussion of legislative and executive recognition of Indian sovereignty, see ROYAL COMM'N ON ABORIGINAL PEOPLES, PARTNERS IN Confederation: AbORiginal PEOPLes, SElf-Government, AND THE Constitution (Ottawa, 1993).

259. [1996] 137 D.L.R. 4th 289. See also Worcester v. Georgia, 31 U.S. (6 Pet.) 515, 559-60 (1832); Johnson v. M'Intosh, 21 U.S. (8 Wheat.) 543, 573 (1823). Numerous authorities have discussed the merits of Johnson v. M'Intosh and Worcester v. Georgia decisions. See, e.g., The Queen v. Sioui [1990] 70 D.L.R. 4th 427; Connoly v. Woolrich [1867] Rapports Judiciares Revises de la Quebec 75; ROYAL COMM'N ON ABORIGINAL PEOPLES, supra note 258.

260. See Brian Slattery, Understanding Aboriginal Rights, 66 CAN. B. REV. 727, 739 (1987).

261. [1990] 70 D.L.R. 4th 427. See also Mitchell v. Peguis Indian Band [1990] 71 D.L.R. 4th 193, 209; Canadian Pacific Ltd. v. Paul [1988] 53 D.L.R 4th 487. 
between sovereign nations." ${ }^{262}$ The Court continued by noting:

The mother countries did everything in their power to secure the alliance of each Indian nation and to encourage nations allied with the enemy to change sides. When these efforts met with success, they were incorporated in treaties of alliance or neutrality. This clearly indicates that the Indian nations were regarded in their relations with the European nations which occupied North America as independent nations. ${ }^{263}$

The Court noted that the Crown allowed these nations to retain autonomy in their internal affairs, ultimately concluding that the Indian Nations' sovereignty was sui generis in a manner similar to the United States' domestic dependent nations. "[R]elations with Indian tribes fell somewhere between the kind of relations conducted between sovereign States and the relations such States had with their own citizens."264

Similarly, in The Queen $v$. Van der Peet the Court noted:

[Indian] people have always enjoyed, whether as nomadic or sedentary communities, some kind of social and political structure. Accordingly, it is fair to say that prior to the first contact with the Europeans, the native people of Northern America were independent nations, occupying and controlling their own territories, with a distinctive culture and their own practices, traditions and customs. ${ }^{265}$

The Court also asserted that the Aboriginal rights protected by the Constitution Act of 1982 can be best understood as:

[F]irst, the means by which the Constitution recognizes the fact that prior to the arrival of Europeans in North America the land was already occupied by distinctive Aboriginal societies, and as, second, the means by which that prior occupation is reconciled with the assertion of Crown sovereignty over Canadian territory. ${ }^{266}$

262. The Queen v. Sioui, 70 D.L.R. 4th at 448.

263. Id. at 448 .

264. Id. at 437.

265. The Queen v. Van der Peet [1996] 137 D.L.R. 4th 289, 329-30.

266. Id. at 309-10. This language was repeatedly approved in subsequent cases. See, e.g., Corbiere v. Canada [1997] 142 D.L.R. 4th 122, 131; The Queen v. Gladstone [1997] 137 D.L.R. 4th 648, 681; The Queen v. Cote [1996] 138 D.L.R. 4th 385, 406. See also The Queen v. Adams [1996] 138 D.L.R. 4th 657, 666, 679; The Queen v. Van der Peet [1996] 137 D.L.R 4th 289, 303-09, 330-32, 334, 372; Calder v. Attorney-General of British 
In Corbiere v. Canada, ${ }^{267}$ the Court echoed these sentiments, suggesting that the protection afforded by the Constitution "may be particularly important to traditional forms of Aboriginal government which do not necessarily fall into the current western understanding of "democratic," "268 such as those which rely on "hereditary chiefs or government based on consensus." 269

It would be thought from these statements and from the judiciary's insistence that Aboriginal rights are categorized as such because "they constitute or have constituted an integral part of the distinctive culture of the particular Indians," 270 that Aboriginal sovereignty would be viewed as an inherent right in Canada which could be affected only through consensual agreement. ${ }^{271}$ This view has not, however, been accepted by all members of the judiciary. The Court in The Queen v. Sioui ${ }^{272}$ asserted that Aboriginal sovereign rights could not be unilaterally extinguished. "[T]he very definition of a treaty . . . makes it impossible to avoid the conclusion that a treaty cannot be extinguished without the consent of the Indians concerned." ${ }^{273}$ In The Queen $v$. Van der Peet, ${ }^{274}$ the Court quoted with approval Asch's and Macklem's statement that Aboriginal rights "inhere in the very meaning of Aboriginality." 275 Generally, however, it is nevertheless

Columbia [1973] S.C.R. 313, 328, 390. The Van der Peet Court also recognized that these Aboriginal societies had "a prior legal regime giving rise to Aboriginal rights which persist, absent extinguishment." 137 D.L.R. 4th at 368 . According to the doctrine of continuity, the lex loci of these Aboriginal societies continued despite British claims of sovereignty. See id. at 348.

267. [1996] 142 D.L. R. 4th 122.

268. Corbiere, 142 D.L.R. 4th at 136 (quoting THOMAS ISSAC, ABORIGINAL LAW: CASES, Materials AND COMMENTARY 305 (1995)).

269. 1 .

270. Delgamuukw v. British Columbia [1993] 104 D.L.R. 4th 470, 681. See also The Queen v. Paul [1997] 145 D.L.R. 4th 472, 477; Corbiere v. Canada [1997] 142 D.L.R. 4th 122, 131-32; The Queen v. Marshall [1997] 146 D.L.R. 4th 257, 263; [1996] The Queen v. Cote 138 D.L.R. 4th 385, 406-07; The Queen v. Adams [1996] 138 D.L.R. 4th 657, 667-70; The Queen v. Van der Peet [1996] 137 D.L.R. 4th 289, 310.

271. Obviously, Indian Nations assert that their sovereignty is inherent and thus cannot be unilaterally abrogated. For example, examine the evidence presented by a representative of the Canadian Indian Lawyers' Association, Ms. Judy Sayers, before the Special House of Commons Committee on Indian Self-Government. See CaNADa House of COMmons SPECIAL COMMITTEE ON INDIAN SELF-GOVERNMENT IN CANADA: REPORT OF THE SPECIAL COMMITTEe 44 (Ottawa: Queen's Printer, 1983) (the Penner Report). See also Asch, supra note 26, at $480-81$. This view was accepted by the Royal Commission on Aboriginal Peoples. See generally ROYAL COMM'N ON ABORIGINAL PEOPLES, supra note 258.

272. [1990] 70 D.L.R. 4th 427.

273. Id. at 435.

274. [1996] 137 D.L.R. 4th 289.

275. Id. at 300 (quoting Michael Asch \& Patrick Macklem, Aboriginal Rights and Canadian Sovereignty: An Essay on $R$ v. Sparrow, 29 ALTA. L. REv. 498, 502 (1991)). 
accepted that Aboriginal rights, including Aboriginal self-government, may be unilaterally regulated ${ }^{276}$ by the federal government ${ }^{277}$ if it is able to justify the infringement within the tests espoused in The Queen $v$. Sparrow. ${ }^{278}$

The Canadian government views Aboriginal self-government agreements to be based "either on the principle of 'delegated authority'. . . or through a form of 'legislative authority'... . which can be unilaterally changed or withdrawn by the Federal Parliament." 279 The governmental position is that Canadian state sovereignty extinguished Aboriginal sovereignty, and thus, the latter sovereignty is treated as being dependent upon legislative acknowledgment, rather than inherent sovereignty. ${ }^{280}$ These governments have insisted that sovereignty operates within the terms and confines of that legislation. ${ }^{281}$ As with the United States' position, under this view, Aboriginal sovereignty is subject to the direction of the Federal

276. If it is accepted that Aboriginal sovereignty is an existing Aboriginal right that had not been extinguished prior to 1982, as a result of, inter alia, Constitution Act, $\$ 35(1), 1982$ (Can.), the Federal government may not extinguish Aboriginal sovereignty. See, e.g., The Queen v. Paul [1997] 145 D.L.R. 4th 472, 482; The Queen v. Van der Peet [1996] 137 D.L.R. 4th 289, 303; The Queen v. Sparrow [1990] 70 D.L.R. 4th 385, 400-01. See also ROYAL COMM'N ON ABORIGINAL PEOPLES, supra note 258.

277. See, e.g., The Queen v. Sikyea [1964] 43 D.L.R. 2d 150, 154; The Queen v. Derriksan [1976] 71 D.L.R. 3d 159; Kruger v. The Queen [1978] 75 D.L.R. 3d 434; Moosehunter v. The Queen [1981] 123 D.L.R. 3d 95, 104; Horseman v. The Queen [1990] 1 S.C.R. 901.

278. [1990] 70 D.L.R. 4th 385. See also The Queen v. Badger [1996] 133 D.L.R. 4th 324, 354-55; The Queen v. Van der Peet 137 D.L.R. 4th 289, 302-03, 337-39; The Queen v. Gladstone [1996] 137 D.L.R. 4th 648, 682; The Queen v. Cote [1996] 138 D.L.R. 4th 385, 406. See generally Asch \& Macklem, supra note 275 (discussing Aboriginal rights in relation to the decision of The Queen $v$. Sparrow).

279. Asch, supra note 26, at 480 (footnotes omited). Note, however, that Premier Rae of Ontario recently suggested that Aboriginal sovereignty was inherent. See id. at 481 . Aboriginal rights of self-government cannot be extinguished by provincial legislation. See, e.g., The Queen v. Paul [1997] 145 D.L.R. 4th 472, 477-78, 480, 492; Delgamuukw v. British Columbia [1993] 104 D.L.R. 4th 289, 537, 539, 681. As in the United States, general provincial legislation may regulate activities within Indian lands, but only to the extent that it is not inconsistent with any treaty. See, e.g., The Queen v. Paul [1997] 145 D.L.R. 4th 472, 480-81, 88; Delgamuukw v. British Columbia [1993] 104 D.L.R. at 539; The Queen v. Sioui [1990] 70 D.L.R. 4th 427; Simon v. The Queen [1985] 24 D.L.R. 4th 390. This limitation is also subject to the Constitution Act, § 35(1), 1982 (Can.). See Delgamuukw, 104 D.L.R. 4th at 492; Sparrow, 70 D.L.R. 4th at 686 . Moreover, provincial legislation will be taken to affect Indian lands only where the Aboriginal use of the land or resource is incompatible with the purpose underlying the legislation. Paul, 145 D.L.R. 4th at 492.

280. See Asch, supra note 26, at 481.

281. See id. at 480-81 (discussing a letter from P. H. Cadieux, Minister of Indian Affairs and Northern Development, to W. Erasmus, President, Dene Nation, Feb. 6, 1990). 
government. ${ }^{282}$

Thus, while there is some dispute as to the source of Aboriginal sovereignty, it appears that the co-existence of Aboriginal rights of selfgovernment with the Canadian government's sovereignty is accepted by all arms of government.

\section{Australia}

While even today many of the Aboriginal communities in Australia are geographically isolated from the general Australian community, their status as domestic dependent nations has only been given rare recognition. The strongest assertion of the status of these communities as domestic dependent nations can be found in Justice Willis' judgment in The Trial of Bonjon. ${ }^{283}$

Justice Willis believed the New South Wales colony stood "on a different footing from some others, for it was neither an occupied place, nor was it obtained by right of conquest and driving out the natives, nor by treaties." 234 The Aboriginal peoples of the country were "dependent allies, still retaining their own laws and usages, subject only to such restraints and qualified control as the safety of the colonists and the protection of the aborigines required." ${ }^{285}$ The "Aborigines . . . remained unconquered and free, but dependent tribes, dependent on the colonists as their superiors for protection." 286 Such dependency did not, however, amount to a surrender of Aboriginal sovereignty. ${ }^{287}$ Relying on the United States' case law, Justice

282. See, e.g., Berg, supra note 149, at 387; Mason, supra note 203, at 423-24, 437-39; Bryant, supra note 9, at 291; Philip J. Smith, Indian Sovereignty and Self-Determination: Is a Moral Economy Possible?, 36 S.D. L. REV. 299, 300 (1991); Raidza Torres, The Rights of Indigenous Populations: The Emerging International Norm, 16 YALE J. INT'L L. 127, 143 (1991).

283. Bonjon was charged with the murder of James Weir at Geelong on September 2, 1841. The judgment is set out in The PORT PhILlip GAZETTE (1841), in Papers Relative to South Australia, Vol. 8, IUP (filed in the Rare Books Collection, University of Adelaide Library, Australia) [hereinafter Bonjon]. Ultimately the learned judge was considered too radical for the small town and was removed from the bench. See also, e.g., Statements of Justice Cooper, Supreme Court, May 15, 1851, in Register, May 16 \& 20, 1851; Address to Grand Jury, Supreme Court, Nov. 3, 1840, in Adelaide Chronicle, Nov. 4, 1840; Jury's Statement, The Trial of Tukkum, Nyalta Wikkannin and Kanger Warli, Supreme Court, May 15, 1851, in Register, May 16 \& 20, 1851.

284. Bonjon at 152. Justice Willis declared New South Wales could not have been acquired by discovery, for New South Wales was not unoccupied when it was taken by the colonists. The country was not unoccupied; he noted, when the first settlers landed a body of Aborigines appeared on the shore, armed with spears, which they threw down as soon as they found the strangers had no hostile intention. See id. at 150.

285. Id.

286. Id.

287. Id. 
Willis held the Aboriginal people were not reduced to the status of Crown subjects, but retained their traditional rights even in the face of British sovereignty. ${ }^{288}$ Justice Willis, therefore, concluded "the Aborigines [are] a distinct though dependent people, and entitled to be regarded as self governing communities." 289

In accordance with this finding, Justice Willis held that disputes between Aboriginal persons inter se should be governed by "their own rude laws and customs," refusing to exercise jurisdiction over the matter before him. ${ }^{200}$ He believed it would be wrong to extend English law to such persons "[f]or in Australia it is the colonists and not the Aborigines [who] are the foreigners; the former are exotris, the latter indigenous; the latter the native sovereigns of the soil, the former uninvited intruders." ${ }^{291}$ The mere introduction of the common law did not serve to extinguish such Aboriginal customary law which continued to govern the rights of these peoples in their communities. It would be highly unjust, he declared, if Aboriginal sovereignty could be so easily abrogated by the introduction of white society:

Indeed as Monsieur de Vattel very justly says, 'whoever agrees that robbery is a crime and that we are not allowed to take forcible possession of our neighbours property, will acknowledge, without any other proof, that no nation has a right to expel another people from the country they inhabit in order to settle in it herself. ${ }^{292}$

Justice Willis consequently concluded that Aboriginal sovereignty had not been legitimately extinguished through colonial settlement and could continue to be exercised, at least concurrently with the Crown. British settlement of Australia was an unlawful act in defiance of Aboriginal sovereignty, and until that sovereignty was ceded or abrogated in some other manner, it continued to be exercised by Aboriginal peoples as domestic dependent nations.

Justice Willis' approach was not, however, accepted by subsequent courts. ${ }^{293}$ Aboriginal peoples were treated as being amenable to colonial

288. See id.

289. Id.

290. Justice Willis pointed to Jamaica and St. Vincent as examples of colonies where English law prevails, while the Aboriginal people maintain self-government as dependent allies. Ultimately, the authorities did not proceed with the charge. Unable to produce certain crucial pieces of evidence, the Crown Prosecutor entered a nolle prosequi.

291. Id. at 152.

292. Id. (quoting Monsieur de Vattel).

293. See discussion supra note 283. 
laws, ${ }^{294}$ and the notion of Aboriginal sovereignty, even in the form of domestic dependent nations, was rejected. Thus, in Coe v. Commonwealth, ${ }^{295}$ a majority ${ }^{296}$ of the High Court of Australia rejected the plaintiff's claim for Aboriginal sovereignty, even in the form of domestic dependent nations.

Writing for the majority, Justice Gibbs, with whom Justice Aickin agreed, believed that the claim of Aboriginal sovereignty was so outrageous and vexatious that it amounted to an abuse of process. ${ }^{297}$ Nevertheless, he went on to consider the plaintiff's claim and the possible application of the doctrine of domestic dependent nations. ${ }^{298}$ Unlike the North American Indians, he believed the Aboriginal peoples of Australia were not a "distinct political society" separated from the rest of the Australian people who could exercise sovereignty concurrently with the Crown. ${ }^{299}$ Justice Gibbs developed an extremely eurocentric test for the recognition of Aboriginal sovereignty, asserting that an Aboriginal Nation had to have distinct legislative, executive and judicial organs before its sovereignty could be recognized. ${ }^{300}$ Applying this stringent test, he declared the "contention that there is in Australia an Aboriginal nation exercising sovereignty, even of a limited kind, is quite impossible in law to maintain." 301 More recently, in

294. See, e.g., In re Phillips (1987) 72 A.L.R. 508; Coe v. Commonwealth (1979) 53 A.L.J.R. 403; The Queen v. Wedge (1976) 1 N.S.W.L.R. 581.

295. The plaintiff submitted that the Aboriginal Nation had from time immemorial enjoyed exclusive sovereignty over the Australian continent. He argued that the sovereign and territorial rights exercised by the many tribes, clans and bands living and traveling across the Australian continent formed part of the interlocking system of rights and responsibilities of the sovereign Aboriginal Nation. The claims of Captain Cook, Captain Phillip and others, on behalf of the Crown were contrary to these rights and could not, therefore, legitimately extinguish the Aboriginal sovereign title. These sovereign rights, it was suggested, were retained by the Aboriginal Nation; therefore, the Australian Commonwealth was an unlawful government, at least as far as the Aboriginal people were concerned. Coe v. Commonwealth (1979) 53 A.L.J.R. 403. As noted, in Mabo v. Queensland (1992) 175 C.L.R. 1, the High Court of Australia invoked the act of state doctrine as purportedly preventing it from considering the validity of the claim to sovereignty in Australia.

296. Justice Murphy asserted that he would allow a plaintiff to argue that sovereignty to Australia resided in the Aboriginal Nation. Relying on, inter alia, Western Sahara, 1975 I.C.J. 12 (Oct. 16) he suggested the traditional characterisation of the annexation of the Australian continent as one of 'occupation' could be questioned to thereby undermine the foundations of the Australian governments sovereignty. See Coe v. Commonwealth (1979) 53 A.L.J.R. at 412.

297. Coe v. Commonwealth (1979) 53 A.L.J.R. at 412.

298. See id.

299. Id. (quoting Chief Justice Marshall in Cherokee Nation v. Georgia, 30 U.S. (5 Pet.) $1,17(1831)$ ).

300. Id. The judicial organs must also apply law of a European type. See id.

301. Id. Justice Gibbs recognized questions of sovereignty and locus standi to be interrelated, noting his denial of Aboriginal sovereignty meant the plaintiff had no standing to make these claims. See id. at 409 . Justice Jacobs believed he could not consider whether 
Wik Peoples v. Queensland, ${ }^{302}$ Justice Kirby reaffirmed Justice Gibbs' conclusion by noting that the "indigenous people of Australia [did not] enjoy" 303 the status of domestic dependent nations.

\section{REVERSION OF ABORIGINAL SOVEREIGNTY}

The final matter for consideration is the legal rights of Aboriginal peoples, where it is concluded that the colonial occupation of their country was an invalid invasion of their sovereign rights. In the absence of any formal surrender by these Aboriginal Nations, ${ }^{304}$ under international law this sovereignty may be resurrected and restored. Bolstered by international movements supporting decolonization and self-determination, ${ }^{305}$ the

the Crown had properly obtained its sovereign rights to the continent, asserting that it was not open to a municipal court to consider claims adverse to the Crown's sovereign rights. See id. at 410 . He did not, however, advert to the question of concurrent sovereignty. Perhaps he would have considered such a claim as this would not involve the denial of the Crown's sovereignty.

302. (1996) 141 A.L.R. 129.

303. Id. at 256.

304. See supra notes 26,64 and accompanying text for discussion on sovereignty.

305. See discussion supra note 2 . The International Court of Justice has also recognized the right to self-determination. See Namibia, 1971 I.C.J. 16 (June 21); Western Sahara, 1975 I.C.J. 12 (Oct. 16). Note, in practice, the right to self-determination has been confined to "people in the 'classic' colonial context of governance from a distant European power. Anything beyond that is perceived as a potential threat to the territorial integrity of established States." Nettheim, supra note 2, at 6 . To this end, the International Court of Justice has declared the right to territorial integrity and security to be "basic conditions" of international law. See Certain Expenses of the United Nations (Article 17, Paragraph 12 of the Charter), 1962 I.C.J. 151, 168 (July 20). See also Bryant, supra note 9, at 267, 268, 274-75; Falk, supra note 198, at 26; Williams, supra note 9, at 18; SANDERS, supra note 40, at 27; Torres, supra note 282, at 162; Pearce, supra note 2, at 376-77; G. Nettheim, 'Peoples' and 'Populations': Indigenous Peoples and the Rights of Peoples, in THE RIGHTS OF PEOPLES 107, 118-19 (James Crawford, ed., 1992); Louis Henkin, The United Nations and Human Rights, in 19 INT'L ORG. 504, 512-13 (1965); Rudolph Ryser, Fourth World Wars: Indigenous Nationalism and the Emerging New International Political Order, in THE QUEST FOR JUSTICE: ABORIGINAL PEOPLES AND ABORIGINAL RIGHTS 204 (Menno Bolt \& J. Anthony Long eds., 1985); HECTOR GROS ESPIELL, THE RIGHT TO SELF-DETERMINATION: IMPLEMENTATION OF United Nations Resolutions 13, U.N. Doc. E/CN.4/Sub.2/Rev.1 (1980). Emerson believes that the right is confined in this manner as a matter of law, not just practice.' See RUPERT EMERSON, SELF-DETERMINATION REVISED IN THE ERA OF DECOLONIZATION 63-64 (1964). It is submitted, however, that the preferable view is that the doctrine may legally extend to peoples subjugated by a power within the same country. See, e.g., Berg, supra note 149, at 378-79; SHAW, supra note 149, at 89; CRAWFORD, supra note 21, at 101; BROWNLIE, supra note 49, at 513; Bryant, supra note 9, at 279; ROSALYN HIGGINS. THE DEVELOPMENT OF INTERNATIONAL LAW THROUGH THE POLITICAL ORGANS OF THE UNITED NATIONS 103-04 (1963); UMOZGRIKE OJ UMOZURIKE, SELF-DETERMINATION IN INTERNATIONAL LAW 195-96 (1972); DOV RONEN, THE QUEST FOR SELF-DETERMINATION 5, 6 (1979); AURELIU CRISTESCU, THE RIGHT TO SEL.F-DETERMINATION: HistoriCAl AND CURRENT DEVELOPMENT 
principles of continuity and reversion ${ }^{306}$ may be invoked to resurrect the sovereignty of these dispossessed peoples.

The right of an ousted sovereign to have sovereignty restored under the laws governing belligerent occupation is derived from ultimate de jure title or territorial sovereignty. Sovereign rights do not inure in a belligerent occupant, much less an occupant whose entry was unlawful (ex injuria non oritur jus). The sovereignty of the dispossessed peoples continues, awaiting reversion, despite the loss of territory ${ }^{307}$ and even total illegal annexation. For "the acquisition of a conquered town is only consummated by the treaty of peace, or by the entire subjugation or destruction of the State to which it belongs. "308

Monsieur Vattel believed that even if these people had been completely subjugated, as long as they "did not submit voluntarily and resistance ended merely because of a lack of power" ${ }^{309}$ they could nevertheless retain their sovereignty. If these people continue to exist as a nation, in the absence of a treaty of surrender, their sovereignty can be resurrected. Unless consent to the rule of the conqueror can be implied with the passage of time, where people have been forcibly subjugated, ${ }^{310}$ their sovereign title continues in abeyance and can later be restored. Even a state which has been totally extinguished can resume its sovereignty when the resurrected "new" state and the old pre-colonization state are identical. ${ }^{311}$

While the exact legal effects of the reversion are unclear, it appears the resurrected state resumes full sovereign title. Examples of such reversion of sovereignty include the resurrection of Portugal's sovereignty after the invasion of Philip II of Spain ${ }^{312}$ and modern day Korea, which is seen as exercising the sovereign rights it possessed before the Japanese occupation.

ON THE BASIS OF UNITED NATIONS INSTRUMENTS 21-23 (1981), U.N. Doc. E/UN.4/Sub.2/ 404/Rev. 1. Perhaps most importantly, the contrary view fails to appreciate that territorial integrity does not necessarily conflict with self-determination because the doctrine is flexible and may accommodate concurrent sovereignty. See discussion supra note 2.

306. Reversion is to be distinguished from succession. In the former case, sovereignty is not surrendered and continues in abeyance awaiting revival under the notion of reversion or post liminium. Some comentators have suggested Israel falls into this category. See JULIUS Stone, ISRAel and Palestine: Assault on the Law of Nations (1981).

307. See CRAWFORD, supra note 21, at 412-13.

308. VATTEL, supra note 204, at 212 . The reversion of Aboriginal sovereignty is possible even where lands have purportedly been acquired by conquest. As conquest necessarily involves a derivative acquisition of rights, it implies prior sovereign and territorial rights enjoyed by the original occupants who were subsequently, forcibly displaced. Even these rights, intruded upon by a conquering power, can be restored centuries later.

309. Id. at 213.

310. See CRAWFORD, supra note 21, at 413.

311. See Western Sahara, 1975 I.C.J. 12 (Oct. 16). This was, however, more correctly a case of succession, not continuity.

312. CRAWFORD, supra note 21 , at 413. 
It is also believed the steps taken by the United Nations towards the establishment of the State of Israel ${ }^{313}$ only reinforced the legitimate claims of the Jews to their historical rights. ${ }^{314}$ Prior to Israel's re-entry into these territories, it has been suggested the occupants (i.e., Arabian and Jordanian States) were unlawful belligerents, who therefore acquired no legal title to the country, despite its annexation. In line with this suggestion, many in the international community saw Israel's return to be a legitimate assertion of the State's right to exercise full sovereignty over its kindred lands. ${ }^{315}$

Similarly, current governments of Australia and North America could be seen as unlawful belligerent occupants who failed to obtain legitimate title to these countries. Any acknowledgment of Aboriginal sovereignty today would, therefore, only involve a reinstatement of the historical rights of the legitimate sovereigns. Further, as noted above, the Aboriginal occupants of these countries resisted the invasion of imperial and colonial forces. To a large extent, however, this resistance ultimately weakened and subsided. It is submitted that, in accordance with Monsieur Vattel's sentiments, this was no more than an acknowledgment of the strength of their foes. There was no voluntary submission to the "conquering" powers, nor an acknowledgment of the nation as the legitimate sovereign. Moreover, in varying degrees, these Aboriginal peoples have managed to survive the invasion of their countries and maintain their identity as separate nationalities. Thus, in light of Vattel's works, it appears the decimation of these Aboriginal peoples and the seizure of their lands would not prevent the reversion of their sovereign rights.

In light of the international law outlined in this article, it would appear feasible for Aboriginal peoples to have their original sovereignty recognized and for these people to exercise these rights at least concurrently with the present governmental authority. The hurdles the "occupying" governments put forward as preventing such claims are not insurmountable and the benefits of success are high. Depending on its form, the recognition of Aboriginal sovereignty could provide many benefits. ${ }^{316}$ The right of selfgovernment would provide Aboriginal peoples with a say in their destiny.

313. By a vote of 33 to 13 , with 10 abstentions, the General Assembly adopted Resolution 181(II) recommending Palestine be partitioned into separate Arab and Jewish States. See G.A. Res. 181(II), U.N. Doc. A/64. When Israel declared itself to be an independent State, the United Nations almost immediately recognized it. See STONE, supra note 306, at 154-55.

314. See The Declaration of INDEPEndEnce of THE Jewish State, May 14, 1948 (Isr.), wherein it was stated these peoples were assembled by virtue of the natural and historic right of Jewish people and of the resolution of the General Assembly of the United Nations.

315. More recent examples can be found in Croatia and the Baltic States.

316. In Australia, perhaps the most realistic approach would be to provide Aboriginal communities, such as the Pitjantjatjara peoples, with concurrent sovereignty as domestic dependent Nations. 
If their land is recognized as an international state, ${ }^{317}$ it could provide them with access to the international tribunals and the consequent enforcement of international rights. 
